IZA DP No. 6054

Speeding Up the Product Cycle:

The Role of Host Country Reforms

Liugang Sheng

Dennis Tao Yang

October 2011 


\title{
Speeding Up the Product Cycle: The Role of Host Country Reforms
}

\author{
Liugang Sheng \\ University of California, Davis \\ Dennis Tao Yang \\ Chinese University of Hong Kong \\ and IZA
}

\section{Discussion Paper No. 6054 \\ October 2011}

\author{
IZA \\ P.O. Box 7240 \\ 53072 Bonn \\ Germany \\ Phone: +49-228-3894-0 \\ Fax: +49-228-3894-180 \\ E-mail: iza@iza.org
}

\begin{abstract}
Any opinions expressed here are those of the author(s) and not those of IZA. Research published in this series may include views on policy, but the institute itself takes no institutional policy positions.

The Institute for the Study of Labor (IZA) in Bonn is a local and virtual international research center and a place of communication between science, politics and business. IZA is an independent nonprofit organization supported by Deutsche Post Foundation. The center is associated with the University of Bonn and offers a stimulating research environment through its international network, workshops and conferences, data service, project support, research visits and doctoral program. IZA engages in (i) original and internationally competitive research in all fields of labor economics, (ii) development of policy concepts, and (iii) dissemination of research results and concepts to the interested public.
\end{abstract}

IZA Discussion Papers often represent preliminary work and are circulated to encourage discussion. Citation of such a paper should account for its provisional character. A revised version may be available directly from the author. 
IZA Discussion Paper No. 6054

October 2011

\section{ABSTRACT \\ Speeding Up the Product Cycle: The Role of Host Country Reforms}

We study the effects of policy reforms in the South on the decisions of intrafirm and arm's length production transfers by Northern firms. We show theoretically that relaxing ownership controls and improving contract enforcement can induce multinational companies to expand product varieties to host developing countries, and that a combination of the two reforms has an amplifying effect on product transfers. Consistent with these implications, we find that ownership liberalization and judicial quality played an important role in raising the extensive margin of processing exports in China for the period of 1997-2007. Our findings imply that institutional reforms in developing countries can effectively speed up the product cycle.

JEL Classification: D23, F14, L24

Keywords: product cycle, ownership structure, contract environment, export variety, processing trade, China

Corresponding author:

Dennis T. Yang

Department of Economics

Chinese University of Hong Kong

Shatin, N.T.

Hong Kong

E-mail: deyang@cuhk.edu.hk

\footnotetext{
* The authors would like to thank Robert Feenstra, John Ries, Deborah Swenson, Katheryn Russ and Paul Bergin for invaluable comments and suggestions for this project and to Jessie Pang for her competent research assistance. The authors are also grateful to the support of a Direct Research Grant provided by Chinese University of Hong Kong. We are responsible for all remaining errors.
} 


\section{Introduction}

The introduction of new goods from the innovative North to the South plays an important role in determining trade patterns as well as welfare in developing countries. In a seminal paper on product cycles, Vernon (1966) argues that most of the new products are first produced in the industrialized North because the markets in these countries are large and organizing the early stage of the production in a sophisticated environment is advantageous. Only after a product has become standardized is manufacturing shifted to the less developed South, where wages are lower. Vernon highlights the importance of the product cycle, as shifting manufacturing to the South not only reverses the direction of trade flows but also has significant implications for the world income distribution.

In Vernon's original formulation of the hypothesis, the length of the product cycle depends primarily on market and technological factors, such as the economies of scale, transport cost, and the North-South wage differentials. In subsequent research, many studies have either treated the rate of technology transfer as a random process or modeled the product standardization process as inversely related to the age of the good (e.g., Krugman 1979b; Yang and Maskus 2001; Antràs 2005). As such, these technological parameters do not have an active role in affecting the speed of product adoption in the South. Later studies have considered the actions of entrepreneurs in both the North and the South, who devote resources to technology transfers and adaptation, thus shortening the product cycle (e.g., Mansfield and Romeo 1980; Lai 1998). However, to our knowledge, there has not been a systematic analysis of the role of host country institutions and policies in affecting the pace of introducing new goods. The exceptions are Grossman and Helpman (1991a,b), who argue that government subsidy to imitation in developing countries may increase the average length of the product cycle.

The main purpose of the current paper is to study the effects of host country institutions and policies on the introduction and exporting of new goods in developing countries. We incorporate the role of contract enforcement and ownership liberalization into a product cycle model (Antràs, 2005), which features both intrafirm and arm's length trade. We show that when host government 
imposes ownership restrictions on foreign subsidiaries, outsourcing through market transactions becomes the dominant form of production transfers. With the removal of ownership restrictions, foreign multinationals will introduce new products to the South within firm boundary. The improvement of contract environment in the South reduces the efficiency loss due to the "holdup" problem in an incomplete contract, making the South more attractive. Thus, more new products will migrate to the South. While improvement in each type of institutions expands the product varieties through the optimal choices of the foreign multinationals, the liberalization of ownership structures in combination with better enforcement of contracts amplifies the introduction of new products to the South. In other words, well-coordinated reforms in the host country can accelerate the product cycle. ${ }^{1}$

We test the implications of the model based on the experience of China, where major institutional reforms occurred concurrently with the dramatic expansion of processing trade in the period of 1997-2007. To quantify the effect of institutional improvements on the extensive margin of processing exports, we construct a measure of ownership liberalization at the industry level, employing a unique Chinese natural experiment in which the government gradually lifted the restrictions on ownership structures governing foreign direct investment (FDI). During this period, the Chinese government expanded the list of "encouraged" industries for FDI while reducing the list of "restricted or prohibited" industries, aiming to lift the restrictions on foreign capital inflows as China entered the World Trade Organization (WTO). This list, which was documented in the Guidance for Foreign Investment Industries (NDRC, various years), was first published in 1995 and subsequently revised in 1997, 2002, 2004, and 2007. This sequential relaxation of ownership restrictions on foreign capital cross industries presents a natural experiment to test the effect of ownership liberalization on trade patterns across firms of different organizational forms. In addition, we use an index of judicial efficiency from the World Bank (2008) to approximate the degree

\footnotetext{
${ }^{1}$ New products play a central role in many trade and growth models. Among recent studies on the determinants of the firm product scope in developing countries, Goldberg et al. (2010) find that importing new intermediate inputs is crucial in the introduction of new products by domestic firms. Moreover, Brambilla (2009) finds that variety growth is higher in foreign firms than in domestic firms because of their advantages in technology. Our research on the consequences of the host country policy reforms on product development is complementary to these studies.
} 
of contract enforcement. To measure the export variety of processing trade, we use an index of the extensive margin formulated by Feenstra and Kee (2008).

Our empirical results focus on the effects of policy reforms on the variety of processing exports. We find that encouragement policies towards foreign firms significantly increase the variety of arm's length export, and they have a much larger effect on the variety of intrafirm export. Consistent with our simple model, improvements in the contract environment do not enhance product development in arm's length trade, but they have a strong positive effect on product transfers within multinational companies. Moreover, we find an amplification effect from the coordination of reforms. The Chinese data show that contract enforcement and ownership liberalization are complementary to each other in product development in intrafirm trade: the effect of one reform is larger, if the quality of the other institution is higher. These results are robust to a wide variety of specifications. The strong interaction effect of contract enforcement and ownership liberalization suggests that both reforms in combination are important for new product development in developing countries.

Our paper is related to the burgeoning body of literature on product cycle and incomplete contract, including McLaren (2000), Grossman and Helpman (2002), Levchenko (2007), Antràs (2005), and Nunn (2007). These papers typically focus on the effect of contract enforcement on the boundary of the firm and comparative advantage in international trade. Our point of departure is the emphasis on the consequences of host country policy reforms and the timing of product transfers to the South. Our construction of the ownership liberalization index based on China's institutional changes is also unique, ${ }^{2}$ enabling us to employ a natural experiment for studying the determinants of export variety in processing trade.

Studies on host country institutions and policies that influence trade patterns, rates of innovations, and FDI are also related to our paper. These policies include the enforcement of intellectual property rights (e.g., Chin and Grossman 1990; Diwan and Rodrik 1991; Glass and Saggi 1998; Lai

\footnotetext{
${ }^{2}$ A similar index for 1997 and 2002 was first developed by Blonigen and Ma (2010), who examined the effect of these ownership regulations on the composition of Chinese exports. We expand this index to 1995, 2004, and 2007, and investigate the effects of these policies on the product cycle.
} 
1998; Yang and Maskus 2001), government subsidies to innovation and imitation (e.g., Grossman and Helpman 1991a,b), and institutional variables such as corporate tax rates and bureaucratic delays and corruption (e.g., Gastanaga et al. 1998; Wei 2000). However, none of these studies focuses on the consequences of host government ownership restrictions on product transfers to developing countries. Although some studies have investigated how contract enforcement influences the boundary of the firms, the differential effect of judicial efficiency on intrafirm and arm's length trade is not yet explored.

The current paper is structured as follows. Section II develops a simple model that shows how the removal of ownership restrictions and improvement in legal enforcement may lead to the acceleration of product transfers to the South. We analyze the effect of each policy reform and their amplifying interactive effects. Section III explains the construction of the measures of policy reforms and presents our empirical findings. Section IV concludes.

\section{The Model}

This section relies heavily on the product cycle model of Antràs (2005) to investigate the consequences of relaxing ownership restrictions and improving contract enforcement on the development of new products in developing countries. ${ }^{3}$ The international business literature has long emphasized the prevalence of government's ownership restrictions on multinational companies in developing countries (e.g., Kobrin 1987; Gomes-Casseres 1990), and a large body of economics literature has studied the role of contract enforcement in determining the volume of FDI (e.g., Gastanaga et al. 1998; Wei 2000). Our model shows how host country reforms in ownership regulations and judicial efficiency can effectively speed up the product cycle. Moreover, the model generates four testable predictions that provide a basis for subsequent empirical analysis.

\footnotetext{
${ }^{3}$ Several other papers, including Antràs and Helpman (2008), Acemoglu et al. (2009), and Levchenko (2007), also model partial incomplete contracts. Following the approach of Acemoglu et al. (2009), we focus the analysis on the behavior of the Northern supplier. Our predictions on the consequences of improving contract environments in host countries are consistent with those of Antràs and Helpman (2008).
} 


\subsection{Setup}

The world consists of two countries, the North and the South. Labor is the unique factor of production, which cannot move across the border. There is a unit of consumers with the following preference:

$$
U=\log \left(\int_{0}^{1} y^{\alpha}(z) d z\right)^{1 / \alpha}, \quad 0<\alpha<1
$$

where $y(z)$ is the total consumption of good $z$. The elasticity of substitution between goods is $1 /(1-\alpha)$. Goods can be free traded without any costs. Accordingly, the demand function for a particular good $z$ is given by

$$
y(z)=\lambda p(z)^{-1 /(1-\alpha)}
$$

where $\lambda$ is a function of total expenditure and an aggregate price index. Hence, $p(z)=(\lambda / y(z))^{1-\alpha}$ and the revenue is $R(z)=\lambda^{1-\alpha} y(z)^{\alpha}$.

The final-good producer needs headquarter service $(h)$ and an intermediate input $(m)$ to produce each unit of output. The production function of the final good is

$$
y(z)=\left(\frac{h}{1-z}\right)^{1-z}\left(\frac{m}{z}\right)^{z}, \quad 0 \leq z \leq 1
$$

where $z$ represents the intensity of the intermediate input in the production. As such, $z$ is interpreted as an indicator of standardization of the good production. Moreover, as the production function is only different in $z, z$ also defines variety. If more varieties are produced in the South, we interpret it as the South catching up in the product cycle.

Headquarter service provided by the final-good producer is assumed to be produced only in the North. The intermediate input provided by the supplier can be produced both in the North and in the South. The production of one unit of headquarter service and intermediate input each requires one unit of labor input. However, there is an iceberg trade cost associated with the production of the intermediate input in the South: one unit of sale to the North requires $\tau>1$ units of production in the South. Generally, the sale of the intermediate input is part of the processing export from the 
South to the North.

The final-good producer needs to contract with an intermediate-input supplier to produce the final good. She can either purchase the intermediate input from an independent manufacturing plant or obtain it from an integrated plant. The investment is assumed relation specific; the finalgood producer tailors the headquarter service, and the supplier customizes its intermediate input. Thus, both parties' inputs are useless outside the relationship. As the final-good producer begins the contracting process, the supplier needs to pay a lump-sum transfer $T$ because ex ante a large number of identical and potential manufacturers of the good exist. This lump-sum transfer can make the suppler break even. Therefore, the contract consists of two organizational choices $O \in$ $\{V, A\}$ : vertical integration and arm's length relationship. Vertical integration implies that the Northern producer employs the supplier and owns the intermediate input, and arm's length implies that the supplier is an independent plant who owns the intermediate input. Hence, trade through vertical integration is intrafirm, whereas trade through arm's length is interfirm. Following the classical incomplete contract theory, we assume that organizational form is always contractible and that contractibility of input investment depends on a country's legal system.

To characterize explicitly the effect of contract environment on product transfers to the South, we depart from Antràs (2005) by introducing a probability of a complete contract. Following Acemoglu et al. (2009), we assume that the probability of completing the contract is $\phi_{c}$, where $c \in\{N, S\}$, and $\phi_{c} \in[0,1]$. As the North has a better legal system and higher ability for legal enforcement, it is reasonable to assume $\phi_{N}>\phi_{S}$. Without the loss of generality, we assume $\phi_{N}=1$, i.e., the contract is complete in the North. Without introducing confusion, we ignore the subscript of $S$ in $\phi_{S}$.

The timeline of events is summarized as follows:

1. The final-good producer chooses to locate the supplier from country $c \in\{N, S\}$ and offers a contract $\{O, m, T\}$ to the supplier.

2. The supplier decides whether to accept or reject the offer. If accepting, he makes the lumpsum transfer $T$ to the final-good producer. 
3. Following acceptance of the contract, there is probability $\phi_{c}$ by which the contract is upheld. With probability $1-\phi_{c}$, the contract is not upheld; then, bargaining will occur between the final-good producer and the supplier after the product is produced.

4. After the uncertainty is revealed, $h$ and $m$ are produced.

5. If the contract is upheld, the final-good producer receives the customized intermediate input provided by the supplier. Then, the producer manufactures the final good, and sells it.

6. If the contract is not upheld, the producer and supplier bargain over the revenue. If Nash bargain breaks, no output is produced. If a successful Nash bargain occurs, then the producer pays the supplier for the intermediate input, manufactures to produce the final good, and sells it.

The subgame perfect equilibrium (SPE) can be described by a tuple $\left\{O^{*}, c^{*}, T^{*}, h^{*}, m^{*}, y^{*}\right\}$, where $O^{*}$ denotes the optimal organizational form, $c^{*}$ denotes optimal location choice, $T^{*}$ is the optimal size of the lump-sum transfer, and $\left(h^{*}, m^{*}, y^{*}\right)$ are optimal input levels and the corresponding output of good $z$. The equilibrium can be solved backwards.

We now consider the decision of a final-good producer of good $z$ who needs to find a supplier either in the North with higher wage $w^{N}$ or in the South with lower wage $w^{S}$, taking other producers' behavior as given.

\subsection{Supplier in the North}

As the contract is complete in the North, the organizational choice is irrelevant by nature of the incomplete contract theory. Under this scenario, the producer requests the supplier to provide the intermediate input $m$ and her own headquarter service $h$ to maximize profit,

$$
\begin{aligned}
& \max _{h, m} \pi=R-w^{N} h-w^{N} m \\
& \text { s.t. } R=\lambda^{1-\alpha} y^{\alpha}
\end{aligned}
$$


which yields the first-best investment of $m^{*}$ and $h^{*}$. The producer pays the supplier $w^{N} m^{*}$, and sets the lump-sum transfer $T=0$. The producer has the following profit:

$$
\pi^{N}(z)=(1-\alpha) \lambda\left[\alpha / w^{N}\right]^{\alpha /(1-\alpha)}
$$

\subsection{Supplier in the South}

If the producer chooses to offshore the intermediate input from the South, she faces the uncertainty of contract environment. With probability $\phi$, the contract is complete; thus, the producer can achieve the first-best inputs $m^{*}$ and $h^{*}$. However, with probability $1-\phi$, the contract is incomplete; thus, the ex ante contracted input investments are not upheld. In this case, both parties will under-invest their inputs because of the holdup problem. Given the optimal investment bundles in the two scenarios, the producer will set the lump-sum transfer $T$ equal to the expected profit of the supplier. The producer maximizes the expected profits by choosing the optimal organizational form.

We first solve the sub-equilibrium in stages 5 and 6 , when the uncertainty of contract environment is revealed, and then compute the expected profits under different choices of organizational form. At stage 5, because the contract is upheld in the South, we can follow the case of complete contract in the North by solving the following problem:

$$
\begin{aligned}
& \max _{h, m} \pi=R-w^{N} h-\tau w^{S} m \\
& \text { s.t. } R=\lambda^{1-\alpha} y^{\alpha}
\end{aligned}
$$

which yields the following profits for the producer: $\tilde{\pi}_{c}^{S}(z)=(1-\alpha) \lambda\left[\alpha\left(1 / w^{N}\right)^{z}\left(1 /\left(\tau w^{S}\right)\right)^{1-z}\right]^{\alpha /(1-\alpha)}$.

At stage 6, the contract is not upheld in the South. The producer and the supplier know that they will renegotiate their revenue shares after making the investment. Thus, the supplier chooses intermediate input $(m)$ to maximize revenue minus cost (including shipping cost), and the producer chooses headquarter service $(h)$ to maximize her own revenue minus cost. They also know that 
their revenue depends on consumer demand and the simultaneous investment of the other party. Suppose the producer's revenue share is $\beta \in[0,1]$. The value of $\beta$ depends on the organizational form, as we will discuss below.

Therefore, the supplier chooses intermediate input $m$ to solve the following problem:

$$
\begin{aligned}
& \max _{m} \pi=(1-\beta) R-\tau w^{S} m \\
& \text { s.t. } R=\lambda^{1-\alpha} y^{\alpha}
\end{aligned}
$$

Similarly, the producer chooses headquarter service $h$ to solve the following problem:

$$
\begin{aligned}
& \max _{h} \pi=\beta R-w^{N} h \\
& \text { s.t. } R=\lambda^{1-\alpha} y^{\alpha}
\end{aligned}
$$

The solutions to these two problems will yield optimal headquarter service $h(\beta)$ and intermediate input $m(\beta)$. The corresponding profits for the producer and the supplier in stage 6 are $\tilde{\pi}_{1}^{S}(z, \beta)=$ $\beta R(h(\beta), m(\beta))-w^{N} h(\beta)$, and $\tilde{\pi}_{2}^{S}(z, \beta)=(1-\beta) R(h(\beta), m(\beta))-\tau w^{S} m(\beta)$.

At stage 3, the contract environment is unknown to the producer and supplier; thus, their expected profits are the weighted profits from stages 5 and 6 . Hence, the producer can set the lumpsum transfer $T$ equal to the supplier's expected profits $\left[\phi * 0+(1-\phi) \tilde{\pi}_{2}^{S}(z, \beta)\right]$. Thus, if the producer chooses the Southern supplier, her expected profit at stage 1 is

$$
\begin{aligned}
\pi^{S}(z, \beta) & =\phi \tilde{\pi}_{c}^{S}(z)+(1-\phi) \tilde{\pi}_{1}^{S}(z, \beta)+T \\
& =\phi \tilde{\pi}_{c}^{S}(z)+(1-\phi) \tilde{\pi}_{1}^{S}(\beta, z)+(1-\phi) \tilde{\pi}_{2}^{S}(z, \beta) \\
& =\phi \tilde{\pi}_{c}^{S}(z)+(1-\phi) \tilde{\pi}^{S}(z, \beta)
\end{aligned}
$$


where

$$
\begin{aligned}
\tilde{\pi}^{S}(z, \beta) & =\tilde{\pi}_{1}^{S}(z, \beta)+\tilde{\pi}_{2}^{S}(z, \beta) \\
& =R(h(\beta), m(\beta))-w^{N} h(\beta)-\tau w^{S} m(\beta) \\
& =\lambda[1-\alpha \beta(1-z)-\alpha(1-\beta) z]\left[\alpha\left(\beta / w^{N}\right)^{1-z}\left((1-\beta) /\left(\tau w^{S}\right)\right)^{z}\right]^{\alpha /(1-\alpha)} .
\end{aligned}
$$

\subsection{Offshoring and Ownership Choice}

With a decision to offshore its intermediate input to the South, the Northern producer needs to choose an organizational form: vertical integration (intrafirm trade) or arm's length transaction (interfirm trade). We assume a symmetric Nash bargain in relation-specific investment. According to Grossman and Hart (1986), the choice of organizational form affects the parties' outside values. In arm's length transaction, each agent has control over her own input, with zero outside values once the Nash bargain breaks up. This condition implies an equal revenue share for each agent, $\beta^{A}=1 / 2$. However, in vertical integration, the producer owns the plant, and the supplier is an employee. If the supplier does not provide the intermediate input with sufficient quality, the producer can fire the supplier, who will be left with nothing, and seize the intermediate input $m$. The producer can still obtain a fraction $\delta \in(0,1)$ of the output, which in turn generates sale revenue of $\delta^{\alpha} R$. The quasi-rent of this relationship is $\left(1-\delta^{\alpha}\right) R$. Symmetric Nash bargaining leaves each party with its outside option plus one-half of the quasi-rent. Hence, the producer's $e x$ post share in sales revenue is $\beta^{V}=\frac{1}{2}\left(1+\delta^{\alpha}\right)$. Consequently, we have

$$
1>\beta^{V}>\beta^{A}=1 / 2
$$

The Northern producer chooses production locations, as well as the optimal form of organization, if offshoring takes place in the South. Therefore, her ex ante expected profit is

$$
\pi(z)=\max _{c \in\{N, S\}, O \in\{V, A\}}\left\{\pi^{N}(z), \pi^{S}\left(z, \beta^{A}\right), \pi^{S}\left(z, \beta^{V}\right)\right\}
$$


It can be shown that

$$
\left(\frac{\pi^{N}(z)}{\pi^{S}(z, \beta)}\right)^{\frac{1-\alpha}{\alpha z}}=\frac{B^{O}(z)}{\omega / \tau}
$$

where

$$
B^{O}(z)=\left[\phi+(1-\phi) \frac{1-\alpha \beta(1-z)-\alpha(1-\beta) z}{1-\alpha}\left[\beta^{1-z}(1-\beta)^{z}\right]^{\alpha /(1-\alpha)}\right]^{-\frac{1-\alpha}{\alpha z}}
$$

and $O \in\{V, A\}$. Hence, for a given $z, \pi^{N}(z)>\pi^{S}\left(z, \beta^{O}\right)$ if and only if $B^{O}(z)>\omega / \tau$, and $\pi^{S}\left(z, \beta^{V}\right)>\pi^{S}\left(z, \beta^{A}\right)$ if and only if $B^{V}(z)<B^{A}(z)$.

Figure 1 shows the coexistence of the three types of production modes: exclusive production in the North, vertical integration across the border, and arm's length production sharing. We can obtain the following key lemma of Antràs (2005) (see the proof in the Appendix):

Lemma 1 For the most headquarter-service-intensive (least-standardized) goods, the intermediate input production remains in the North. For the relatively less headquarter-service-intensive goods, the intermediate input production is likely to be offshored through vertical integration. For the least headquarter-service-intensive goods, the intermediate input production is outsourced to the South.

Note that under certain conditions, vertical integration may not be an optimal arrangement for the supply of the intermediate input. For instance, if the $\omega / \tau$ line goes through the intercept of $B^{V}$ and $B^{A}$ curves, the production in the North and arm's length trade will dominate vertical integration. Intrafirm arrangement is also not optimal if the trade cost is too high, which lowers the $\omega / \tau$ line below the $B^{V}$ curve, or if the contract enforcement is too poor, which raises the $B^{V}$ curve above the $\omega / \tau$ line. The coexistence of the three organizational forms provides a rich analytical framework.

Our primary interest is to examine the role of host country policy reforms in affecting the pace of product transfers to the developing countries. Based on the above lemma, as the product becomes more standardized, the Northern firms will eventually offshore their production of the 
intermediate inputs to the South. Vernon (1966) analyzes the factors determining the length of the product cycle, which refers to the duration between the time of product innovation in the North and the time of adopting its production in the South. As a product matures, factors such as the economies of scale, transport costs, and the North-South wage differentials become important determinants of the locational choice. Antràs (2005) points out that differences in the contract environment in the North and the South will automatically generate a product cycle. In what follows, we will investigate how the relaxation of ownership restrictions for foreign capital inflows, improvements in contract enforcement, and reduction in trade cost may help speed up the product cycle.

Governments in developing countries often restrict the activities of wholly-owned foreign invested firms for reasons including reducing competition with indigenous firms, promoting technology transfer through joint ventures, and controlling strategic sectors (e.g., Kobrin 1987; GomesCasseres 1990; Feenstra and Hanson, 2005). In an extreme case of a strict prohibition of whollyowned foreign firms, the dotted $B^{V}$ curve would disappear from Figure 1. As a result, only arm's length trade would take place. Under this situation, the cutoff between Northern and Southern productions is $\bar{z}_{N A}$. If the ownership restriction is removed, $B^{V}$ becomes part of the choice set. Therefore, the cutoff between North and South productions moves left to $\bar{z}_{N V}$, i.e., more goods will be offshored to the South through vertical integration. However, the extensive margin of arm's length export will be reduced because the supply of some goods will be switched from arm's length production to vertical integration. We summarize these effects of ownership liberalization in the South as the first testable hypothesis: ${ }^{4}$

Result 1 Ownership liberalization, which allows vertical integration in the South, increases the extensive margin of intrafirm export but reduces the extensive margin of arm's length export. As a result, the total variety of Southern export also increases.

\footnotetext{
${ }^{4}$ Ownership liberalization not only promotes the extensive margin of Southern export but also makes its export structure more headquarter-service (or skill) intensive. As these issues go beyond the scope of this paper, we study systematically the skill upgrading of Southern export in a companion paper (Sheng and Yang, 2011).
} 
Improvement in contract environment can be characterized by an increase in $\phi$. As Figure 2 shows, a larger $\phi$ shifts down the $B^{A}$ and $B^{V}$ curves, thus raising the extensive margin of intrafirm export. However, because the intercept between $B^{A}$ and $B^{V}$ is independent of $\phi$, the extensive margin of arm's length export does not change. We state the second hypothesis as follows:

Result 2 Better contract enforcement (a rise in $\phi$ ) increases the extensive margin of intrafirm export, but it has a neutral effect on the product variety of arm's length export. As a result, the extensive margin of Southern export increases.

Trade cost reduction is characterized by a decrease in $\tau$. As Figure 2 shows, a fall in $\tau$ shifts up the horizontal line $\omega / \tau$. This movement raises the extensive margin of intrafirm export, as shipping back the intermediate good produced in the South is now cheaper. However, because the cutoff between intrafirm and arm's length trade remains the same as before, the extensive margin of arm's length arrangement does not change. The following is a straightforward result:

Result 3 Reduction in trade cost (a fall in $\tau$ ) increases the extensive margin of intrafirm export, but it has a neutral effect on the extensive margin of arm's length export. As a result, the extensive margin of Southern export increases.

Given the consequences of individual reforms in Results 1 and 2, exploring the effects of coordinated reforms is also important. If the South relaxes its ownership controls in combination with improvements in legal systems, growth in the extensive margin through intrafirm export would be even larger. As Figure 2 shows, permitting vertical integration alone increases the extensive margin from $\bar{z}_{N A}$ to $\bar{z}_{N V}$, and a simultaneous improvement in contract environment will further expand the extensive margin from $\bar{z}_{N V}$ to $\bar{z}_{N V}^{\prime}$. This framework suggests that contract enforcement and ownership liberalization are complementary factors for product transfers in intrafirm trade: the effect of one reform is larger if the quality of the other institution is higher. This amplification effect is summarized as follows: 
Result 4 (Amplification Effect) Coordinated reforms in ownership liberalization and contract enforcement mutually enhance the effects of each other and amplify the growth of the extensive margin through intrafirm export in the South.

\section{Empirical Analysis}

\subsection{Data and Key Variables}

We test the implications of the model against the Chinese experience when major institutional reforms occurred concurrently with the dramatic expansion of processing trade surrounding China's entry into the WTO. The primary data source we use is the Chinese customs trade data for the period of 1997-2007. The dataset records both the value and quantity of trade at the product level (eight-digit HS code), export locations, firm ownership category, and type of Chinese custom regimes. Our analysis focuses on processing export because it is an integrated part of global production sharing and is closely related to the product cycle. Processing export is an activity that involves a firm in China importing intermediate input from aboard, processing it with other local productive factors, and then exporting the finished goods to international markets. Imported intermediate input is duty-free as long as it is only used for export (Feenstra and Hanson, 2005). In other words, it is the offshored production from developed countries. Processing trade plays a major role in China's international trade, accounting for about 55 percent of total export for the 1997-2007 period.

The firm ownership types in the trade data include Chinese-owned domestic firms, joint ventures, and wholly-owned foreign firms. We consider wholly-owned foreign firms as vertically integrated affiliates (intrafirm trade) and the other two ownership types as unaffiliated plants (arm's length trade).

Our definition of variety is an eight-digit HS product-destination country pair, namely, a product exporting to one particular country. For empirical analysis, China is treated as the South, whereas the rest of the world is treated as the North. For robustness checks, we use high-income 
countries as the North and define variety as an eight-digit HS product. Our main empirical results are very robust to these alternative variable definitions.

The extensive margin can be simply measured as the number of varieties. However, this measure ignores the volume weights of export for different varieties. Therefore, we follow Feenstra and Kee (2008) to construct an extensive margin measure, which takes export weights into account. It also has the advantage of comparability over time, across regions and firm organizational forms. The extensive margin is defined as the following $\Lambda$ ratio:

$$
\Lambda_{i o t}^{r}=\frac{\sum_{j \in J_{i o t}^{r}} v_{i}^{F}(j)}{\sum_{j \in J_{i}^{F}} v_{i}^{F}(j)}
$$

where $j$ denotes a product, and $J_{i o t}^{r}$ is the set of products that province $r$ exports in industry $i$ through organizational form $o$ in year $t$. We define $J_{i}^{F}=\bigcup_{r, o, t} J_{i o t}^{r}$ as the total set of products that China exported to the rest of the world in industry $i$ over all sample years. $v_{i}^{F}(j)$ is the average value of export for product $j$ (i.e., summed over all provinces and organization forms and averaged across years). Note that this measure of the extensive margin changes over time or across provinces or organizational forms only if there is a change in the set of export goods in that province, $J_{i o t}^{r}$. The denominator of the ratio is constant over time, across provinces and organizational forms. By taking the union of all China's exported products over the years, we obtain a consistent comparison across all three dimensions. The value of $\Lambda_{i o t}^{r}$ is in the interval of $[0,1]$.

Table 1 presents the summary statistics of China's processing export and its extensive margin by firm organizational forms. The first two columns show that China's processing export has increased dramatically since its accession to WTO in 2001 and that most of this increase is attributable to wholly-owned foreign firms. During this 11-year period, the share of intrafirm trade in processing export increased from 29 percent to 64 percent. The extensive margin, measured by both number of varieties and Feenstra and Kee's (2008) index, also increased dramatically. A noticeable trend is that the extensive margin of intrafirm trade gradually caught up with the extensive margin of arm's length trade. Whereas product variety in intrafirm trade was systematically below that of interfirm 
trade in the late 1990s, the gap was almost entirely eliminated by 2007.

The rising role of intrafirm export in China is a consequence of ownership liberalization for foreign capital in the face of China's accession to WTO in 2001. Wholly foreign-owned companies were restricted or prohibited in China in the 1990s, whereas joint ventures were encouraged. The main target of such policy was to maximize the access to foreign advanced technologies, as it was perceived that learning costs were much lower within firms. However, China undertook a major regulatory reform regarding foreign trade and investment in the face of the WTO accession in 2001. The WTO Agreement on Trade-Related Investment Measures (TRIMs) explicitly precludes WTO members from imposing restrictions or distortions on foreign investment. To comply with the provisions of the TRIMs agreement, China modified many laws regulating trade and foreign investment, encouraging foreign firms to compete on an equal basis with Chinese companies. For instance, for the first time in 2001, the revision of "the Rules for the Implementation of the Law of the People's Republic of China on Foreign Capital Enterprises" confirmed foreigners' rights to their intellectual properties. It stated that "industrial property rights and proprietary technology to be contributed as investment by a foreign investor must be owned by the foreign investor." In previous documents, industrial property rights and proprietary technology were treated as part of capital investment, and they could not exceed 20 percent of the total foreign capital. ${ }^{5}$ These policy reforms resulted in changes in the ownership structures of FDI to China. Joint ventures played a dominant role in FDI inflows before 2001. By 2008, however, foreign-owned firms accounted for 78 percent of China's annual FDI inflow (NBS, 2009b).

We construct a unique measure of ownership liberalization using the official list from the Chinese government that specifies which industries are encouraged, restricted, or prohibited for foreign investment. This list, provided in the Catalogue for the Guidance of Foreign Investment Industries (NDRC, various years), was first published in 1995 and was revised subsequently in 1997, 2002, 2004, and 2007. For encouraged industries, foreign investors have more freedom in choosing their ownership structures, and they enjoy other advantages such as preferable corpo-

\footnotetext{
${ }^{5}$ See Branstetter and Lardy (2008) for detailed discussions on China's policy changes upon its WTO accession.
} 
rate tax rates, low costs of land, and duty-free for imported inputs. In contrast, for restricted or prohibited industries, the Chinese government usually imposes stringent restrictions on ownership structures and high entry cost for foreign investors.

The listed industries or products under encouragement or restriction policies follow roughly the structures of the 2002 China Standard Industrial Classification (CSIC) coding, in which each listed item could be matched with multiple products in different industries. Based on a systematic key word search, an industry is identified as under an encouragement policy (or restriction policy) if a listed item can be matched with the industry under the 2002 CSIC codes, a method consistent with Blonigen and Ma (2007). ${ }^{6}$ To provide an overview of the ownership liberalization process, we count the number of industries under encouragement and restriction policies in the four digits of the 2002 CSIC coding for each year. The results are presented in Figure 4. The data show a clear trend of ownership liberalization for foreign capital from 1995 to 2007. Two major jumps in encouraged industries are found in 2002, the year after China's accession to WTO, and in 2007, the year after the Chinese government promised to remove most of the trade and investment protections. By 2007, only 54 out of the 482 industries in the manufacturing sector still had restrictions for foreign capital. These restrictions were only imposed on selected products in these industries.

For subsequent regression analysis, we construct two proxies for ownership liberalization at the industry level: an encouragement policy indicator and a restriction (includes prohibited) policy indicator. We assign the value of 1 for encouragement (or restriction) policy in an industry if at least one product in that industry is formally stated on the government list of encouragement (or restriction). Otherwise, we assign the value of 0 to that industry. We also assume that there are no policy changes until a formal revision is announced in the published Catalogue. These two policy indicators capture the differences in ownership regulations between industries with and without policy interventions.

For the measurement of contract environment, we follow the literature on the influence of

\footnotetext{
${ }^{6}$ We use two documents to identify the associated CSIC industrial codes for the key words: 2002 CSIC and 2005 Product Classification for Statistics (NBS, 2005). The 2005 PCS is based on the 2002 CSIC, but it is more disaggregated, containing more than 34,000 products at the 10-digit level.
} 
institutional quality on the trade pattern (Nunn, 2007; Levchenko, 2007; Feenstra et al., 2010). These studies use the indexes of doing business in 30 provincial capitals in China published by the World Bank (2008). Specifically, we use a "court cost" variable, which is measured as the ratio of official costs of going through court procedures to the debt claim. Higher "court cost" indicates an inefficient, rent-seeking legal system, implying a lower probability of upholding contracts between firms. For convenience of interpretation, we construct a court efficiency measure, which equals 0.5 minus the ratio of court cost, as in Feenstra et al. (2010). ${ }^{7}$ The spatial differences in court efficiency in China are substantial. The Southeast coastal provinces usually have higher levels of court efficiency than do interior and northern provinces.

To approximate trade cost, we use the cumulative number of national policy zones that had been opened up to a year in a specific province. ${ }^{8}$ China began to establish special economic zones for export in the early 1980 in coastal cities. Owing to their initial success, special zones were expanded into inland cities (Wang, 2010). These policy zones include Economic and Technological Development Zone, High-Tech Development Area, Bonded Area, Export Processing Zone, and other types. Multinational companies in these zones enjoy various advantages, including lowered corporate tax rate of 15 percent, duty free for imported inputs, no import quotas, low costs of land, and no property tax in the first five years. There are also additional benefits for foreign firms if they export most of their products. The data reveal two booming periods of policy zones: the first is 1990-1993 when the cumulative number of zones jumped from 18 to 130 , and the second is 1999-2003 when the number increased from 139 to 196. By 2006, a total of 221 policy zones had been established in China. Their existence has reduced the costs of international trade.

\footnotetext{
${ }^{7}$ World Bank (2008) also provides two other measures of contract environment: "court time," which measures the time interval between the time the plaintiff files the lawsuit and the time of payment, and "court rank" of the court system in each provincial capital based on the measures of "court cost" and "court time." As Nathan Nunn points out in Feenstra et al. (2010), either a very short period of time or a very long period of time can be an indicator of inefficient legal system; as such, there is no monotonic relationship between court time and court efficiency. We also agree with this point; thus, we use the court cost as a measure of judicial efficiency in our study.

${ }^{8}$ The data source is China Development Zone Review Announcement Catalogue (NDRC, 2007). We adopt this measure of trade cost rather than tariff because of two reasons. First, all imports for processing export are duty-free in China, and outward export tariffs are difficult to compute. Even if outward export tariffs are available at the product level, there is no variation across provinces. Second, the setup of national policy zones requires authorization from the central government, which can be arguably considered as an exogenous process beyond the control of provincial governments. Therefore, the endogeneity problem is not a major concern.
} 


\subsection{Empirical Specification}

We assess the role of institutions and policies as determinants of product varieties in processing exports. The dependent variable for analysis, $\ln \left(E M_{\text {irot }}\right)$, is the log value of the extensive margin of industry $i$ and organizational form $o$ in province $r$ and year $t$. The principle explanatory variables are (1) an indicator variable for organizational form (i.e., $D_{\text {irot }}=1$ for intrafirm export, and $D_{\text {irot }}=0$ for arm's length export); (2) two indices of policy reforms, i.e., $E P_{i t}$ for encouragement policy and $R P_{i t}$ for restriction policy; (3) an index of court efficiency, which approximates the degree of contract enforcement or institutional quality $\left(Q_{r}\right)$; and (4) the cumulative number of national policy zones, a proxy for trade $\operatorname{cost}\left(T C_{r t}\right)$. The basic estimation equation is

$$
\begin{aligned}
\ln \left(E M_{\text {irot }}\right)= & \alpha_{1} D_{\text {irot }}+\alpha_{2} E P_{i t}+\alpha_{3} R P_{i t}+\alpha_{4} Q_{r}+\alpha_{5} T C_{r t} \\
& +\beta_{1} E R_{i t} D_{\text {irot }}+\beta_{2} R P_{i t} D_{\text {irot }}+\beta_{3} Q_{r} D_{\text {irot }}+\beta_{4} T C_{r t} D_{\text {irot }} \\
& +\sum_{m} \gamma_{m} G_{m r}+\gamma_{p} \ln \left(P D E N_{r t}\right)+\gamma_{y} \ln Y_{r t}+\sum_{n} \gamma_{n} V_{\text {irt }}+\delta_{i}+\delta_{t}+\epsilon_{\text {irot }} .
\end{aligned}
$$

This specification controls for a set of province-specific geographic variables $\left(G_{m r}\right)$, including the $\log$ value of minimum arc distance to two major ports in China (i.e., Shanghai and Hong Kong) and two dummy variables indicating whether a province has an international border and a coastal line, respectively. Accordingly, we do not use provincial dummies to control for regional fixed effects. We also add population density $\ln \left(P D E N_{r t}\right)$ and provincial real output $\ln Y_{r t}$ as controls for the market size effect that larger economies usually export more varieties (Krugman, 1979a). Moreover, following Romalis (2004) and Nunn (2007), we also include the interaction $\left(V_{\text {nirt }}\right)$ of industry-specific factor intensities (i.e., skill intensity and capital intensity) with province-specific factor endowments (i.e., college share and capital output ratio) to capture the effects of locational comparative advantages. ${ }^{9}\left\{\delta_{i}, \delta_{t}\right\}$ are industry and yearly dummies, and $\epsilon_{\text {irot }}$ is a stochastic distur-

\footnotetext{
${ }^{9}$ The college share is defined as the proportion of college graduates in the population above age 5 (NBS, various years). The capital output ratio is defined as capital stock in real terms divided by the real GDP. We obtained the capital stock figures from Bai et al. (2006) and computed real GDP numbers based on China's Compendium of Statistics of 1949-2008 (NBS, 2009a). We rely on the 1995 Chinese National Industry Census (TNICO, 1997) to compute skill intensity by industry, which is defined as the share of workers with college education in total industrial employment,
} 
bance term. Note that the interaction terms between the organizational type and policy variables allow us to test the differential effects of policy reforms on the export variety of intrafirm versus arm's length arrangements.

To avoid the potential contemporaneous correlations between provincial variables with the error term, we use one-year lagged values of trade liberalization measures and those of factor endowment as the benchmark specification. ${ }^{10}$ In addition, as Lu et al. (2008) and Feenstra et al. (2010) point out, the contract environment variable $\left(Q_{r}\right)$ is likely to be endogenous to trade volume, as well as our measure of the extensive margin of processing export. We follow their practice of using former colonial rule, i.e., by British, France, Russia, or a combination of multiple powers, as well as provincial population in 1953 as instruments for contract environment. We will first estimate the above empirical function by OLS and then report the IV results using GMM. We will test for weak instruments using an F-test in the first-stage regression, as recommended by Stock et al. (2002). The F-test statistics are all above the Stock-Yogo criteria of 10, rejecting the notion of weak instruments. Consequently, our discussions and interpretations of the results will be largely based on the IV estimates.

\subsection{Estimation Results}

The first two columns of Table 2 report the OLS and IV estimates of a simplified specification without the interaction of intrafirm dummy variable and key policy variables. Therefore, these are regressions on the determinants of export varieties in the processing trade without distinguishing the differential effect of policies on intrafirm and arm's length trade. Although these results do not provide direct tests on the implications of the model, several results emerge, and they remain stable across the alternative specifications.

First, the estimates for the intrafirm indicator variable are negative, showing that, on average,

and industrial capital intensity, which is defined as the log ratio of net fixed capital over the total industrial employment.

${ }^{10}$ The changes in national polices on ownership regulations are arguably exogenous to industry and provincial variables because the progress of reforms depended largely on the decisions of the central government and the membership rules of the WTO regarding FDI investments. Our empirical analysis reveals that the main estimation results are not sensitive to alternative specifications of these variables. 
the extensive margin of processing export by vertically integrated firms is less than that of the arm's length trade. This result is not surprising because for many years the share of intrafirm trade was less than that of arm's length trade. Second, the encouragement policy and special trade zones generally increase the extensive margin of the Chinese processing export, whereas the restriction policy presents a barrier to the growth of the extensive margin. Court efficiency has a positive but insignificant effect on product variety. This result is consistent with the predictions of the model because improvements in contract enforcement have a neutral effect on processing trade through market transactions (Result 2). Third, the results of the geographic and market size variables are consistent with the existing literature. The further away a region is from the two major ports, the fewer the variety of its export. Coastal provinces have more export varieties than do interior provinces, but having a land-connected international border does not increase variety for Chinese provinces. The significantly positive coefficients for population density and real output imply that the large size of provincial economy leads to more export varieties. The positive coefficients of the interaction terms of skill intensity and college share, and those of capital intensity and capital output ratio suggest that more skill (capital)-intensive industries export more varieties in skill (capital)-abundant regions.

The results from estimating the baseline equation are reported in columns (3) and (4), which lend support to the model's predictions. These specifications include the interactions of organizational form $\left(D_{\text {irot }}\right)$ and other key variables of policies and trade cost. Therefore, they can provide evidence on whether our variables of interest have differential effects on product variety across intrafirm and arm's length trade. Based on the IV estimates, the encouragement policy raises the extensive margins of arm's length and intrafirm processing export by $\exp (0.22)-1=24$ percent and $\exp (0.22+0.168)-1=47$ percent, respectively, compared with those in industries without such policy. This finding is consistent with Result 1, i.e., the relaxation of ownership restrictions strongly increases the variety of intrafirm export as well as total processing export. Perhaps an unexpected result is that the extensive margin of arm's length export also increases, which goes beyond the prediction of the model. However, this result is hardly surprising because 
the industries targeted by the government encouragement policies are also likely to receive other preferential treatments, have reduced bureaucratic barriers, and encounter lower entry costs for all types of firms, thus leading to expansion in the processing trade by indigenous Chinese firms and joint ventures. As a result of ownership liberalization, positive productivity spillover to Chinese firms by the growing presence of multinational companies may also promote new product development (Chen and Swenson, 2007). In contrast to ownership liberalization, the restriction policy significantly reduces intrafirm export variety by $1-\exp (-0.267)=23$ percent, whereas it has an insignificant effect on the export variety of arm's length trade.

The IV estimates in column (4) also provide strong empirical support to Result 2. The large coefficient for the interaction of intrafirm and court efficiency suggests that contract enforcement has a significantly positive effect on the export variety of vertically integrated multinational companies. Consistent with the model's prediction, contract environment does not significantly affect the variety of arm's length export because improvements in contract enforcement do not alter the cutoff point between vertical integration and market transactions (Figure 2). Overall, the effect of institutional quality on the product variety of intrafirm trade is large. Consider the inland province of Sichuan, which has a court efficiency index of 8.99 percent, and the coastal city of Shanghai, which has an index value at 26.65 percent. The estimated coefficients imply that, if Sichuan had the same efficient court system as Shanghai, ceteris paribus, the intrafirm export variety would increase by 33 percent $(=\exp (1.633 *(26.65 \%-8.99 \%))-1)$.

The establishment of national policy zones also has significantly positive effects on product development in the processing trade. Based on the estimates, the opening of one additional policy zone in a province is associated with 12 percent and 9 percent increases in intrafirm and arm's length export varieties, respectively. Whereas the effect on vertical integration is consistent with Result 3, the effect of policy zones on arm's length export variety could stem from similar spillover effects or preferable policies related to the opening of special zones for all types of firms, as we discussed in the case of encouragement policy.

Our product cycle model highlights an amplification effect from the coordination of reforms. 
The main idea is that contract enforcement and ownership liberalization are complementary to each other in intrafirm trade: the effect of one reform is larger if the quality of the other institution is higher. To test the implications of Result 4, we present the estimation results of triple interactions of organization form, ownership policies, and contract environment variables in columns (5) and (6) of Table 2. The interaction term of intrafirm-encouragement policy-court efficiency is large and significantly positive, indicating strong complementarity between ownership liberalization and contract environment for multinational companies. To illustrate the size of the amplifying effect, consider two coastal provinces, Shandong and Fujian provinces. In terms of contract efficiency, Shandong is at the median of the provinces, whereas Fujian is ranked at the top 25 percentile. With lower court efficiency in Shandong, having encouragement policy would increase its intrafirm export variety by 13 percent $(=\exp (-0.776+3.201 * 0.28)-1)$, whereas with higher court efficiency in Fujian, the same policy reform would raise its export variety by a much higher 47 percent $(=\exp (-0.776+3.201 * 0.36)-1)$, both relative to industries without the encouragement policy. Therefore, differences in contract environment may lead to significantly different outcomes under the same reform scheme. ${ }^{11}$ This result has important policy implications, suggesting that well-coordinated reforms are crucial for speeding up the product cycle.

\subsection{Sensitivity Analysis}

In this section, we carry out robustness checks for our previous findings. Included in the exercise are alternative measures of the extensive margin, the log value of processing export as the dependent variable, and the use of high-income countries as the North in the regression analysis. We find that all the major results are robust to these alternative specifications.

First, we employ two alternative measures of the extensive margin. The first is a straightforward

\footnotetext{
${ }^{11}$ These estimates imply that the effect of the encouragement policy on product variety is realized primarily through the triple interaction term. When the court efficiency is low, the role of ownership liberalization is very limited. Indeed, when we set court efficiency to zero, the negative coefficient of the interaction of intrafirm indicator and encouragement policy implies that the product variety of intrafirm export is even lower than interfirm exports because of the depressing influence of poor institutions on vertical integration. Theoretically, it is plausible that in this extreme case, the intrafirm offshoring may not exist; hence, the encouragement policy only increases the extensive margin of arm's length export.
} 
count of product varieties, in which variety is still defined as the eight-digit HS product-country pair. The second measure is a redefined variety by an eight-digit HS product, but it is still computed as an extensive margin index following Feenstra and Kee (2008). The number of varieties is reduced because of the broader scope of the definition. Table 3 presents the IV regression results based on these two alternative measures. The results are highly consistent with our benchmark findings, especially in the interaction terms with intrafirm export, reconfirming the fact that the effects of host country reforms on the product cycle are not sensitive to the use of different measures of the extensive margin. One noticeable difference is that the estimated coefficients for the encouragement policy in columns (2) and (3) in Table 3 have turned statistically insignificant positive numbers from previously significantly positive numbers in columns (4) and (6) in Table 2. This finding lends direct support to our hypothesis in Result 1; i.e., ownership liberalization does not increase the extensive margin of arm's length export. Another difference is that the estimated coefficients for the restriction policy in columns (2) and (3) have turned statistically significant positive numbers from insignificant estimates in columns (4) and (6) in Table 2. This result does not go against our theoretical predictions either. It simply implies that ownership controls on foreign ownership may actually increase the export variety of arm's length arrangement because of reduced foreign competition. These two estimation differences suggest that using the number of export variety as the dependent variable may bring additional evidence in support of the theoretical predictions.

Another interpretation of these above differences in estimation results is caused by the weighting schemes in the two measures of the extensive margin. The mechanical count of product variety does not consider the export volume of each product. However, Feenstra and Kee's index is a weighted number of products, in which the weights are the average export value over the sample period. Therefore, it makes sense if the encouragement (restriction) policy increases (deceases) the export value in these preferred industries, as shown in Table 2.

Second, Table 4 presents the IV regression results when the dependent variable is the log export value. The results are again broadly consistent with our benchmark estimation. One noticeable 
finding is that the amplification effect of court efficiency on intrafirm export in the encouraged industry becomes even larger. Taking the same cases of Shandong and Fujian as examples, the encouragement policy now increases the intrafirm export by 10 percent and 56 percent in the two provinces, respectively, relative to those industries without an encouragement policy. Recall that the corresponding amplification effect is 13 percent and 47 percent, respectively, for the benchmark case of the extensive margin.

Lastly, instead of using all other countries as the North, we select all high-income countries as the North. Our definition of high-income countries follows the World Bank's standard classification; China's export to high-income countries accounts for about 89 percent of the total processing export. ${ }^{12}$ Table 5 presents the estimation results based on the high-income country sample using both the extensive margin index and export value as dependent variables. Again, all results are broadly consistent with our benchmark findings.

\section{Concluding Remarks}

In this paper, we study the effects of host country policy reforms on the decisions of multinational companies to make product transfers to developing countries. We incorporate the liberalization of ownership structures and improvement in contract environment into a model of product cycle, which features intrafirm and arm's length trade. Our model suggests that, while ownership liberalization has a direct positive effect on expanding product variety to the South, a simultaneous reform of raising judicial efficiency can achieve a large, amplifying effect. Based on the recent Chinese experience, our empirical findings have provided strong support for the theoretical prediction that policy reforms can speed up the product cycle.

Governments in developing countries aspire to attract direct investment by multinational companies with new products and advanced technologies. However, their strategies vary. Some governments prohibit wholly-owned foreign subsidiaries from entering the local markets; rather, they

\footnotetext{
${ }^{12}$ Taiwan is not included in the World Bank's data, although it qualifies for a high-income region. We add Taiwan into our sample because it is an important trade partner of mainland China.
} 
encourage the establishment of joint-ventures while imposing technology-sharing mandates. Our research suggests that these policies may lead to undesired outcomes. The reason is that, under stringent ownership restrictions, multinational companies will find it unattractive to set up their subsidiaries in the South and bring in advanced products. Instead, they will only transfer less advanced products to the South through arm's length transactions. In contrast, if the host country governments choose to liberalize their ownership structures with concurrent improvements in contract enforcement, they will attract the transfer of more advanced products through intrafirm processing trade. The shortened product cycle will in turn contribute to economic growth and welfare in developing countries.

\section{References}

Acemoglu, D., Johnson, S., Mitton, T., 2009. Determinants of vertical integration: Financial development and contracting costs. Journal of Finance 64 (3), 1251-1290.

Antràs, P., 2005. Incomplete contracts and the product cycle. American Economic Review 95 (4), 1054-1073.

Antràs, P., Helpman, E., 2008. Contractual frictions and global sourcing. In: Helpman, E., D. Marin and T. Verdier (Ed.), The Organization of Firms in a Global Economy. Harvard University Press, pp. 9-54.

Bai, C., Hsieh, C., Qian, Y., 2006. The return to capital in China. Brookings Papers on Economic Activity (2), 61-88.

Blonigen, B., Ma, A., 2010. Please pass the catch-up: The relative performance of Chinese and foreign firms in Chinese exports. In: Feenstra, R. C., Wei, S.-J. (Eds.), China's Growing Role in World Trade. University of Chicago Press, pp. 475 - 509.

Brambilla, I., 2009. Multinationals, technology, and the introduction of varieties of goods. Journal of International Economics 79 (1), 89-101. 
Branstetter, L., Lardy, N., 2008. China's embrace of globalization. In: Brandt, L., Rawski, T. (Eds.), Chinas Economic Transition: Origins, Mechanisms, and Consequences. Cambridge University Press, pp. 633-682.

Chen, H., Swenson, D., 2007. Multinational firms and new Chinese export transactions. Canadian Journal of Economics 41 (2), 596-618.

Chin, J. C., Grossman, G. M., 1990. Intellectual property rights and North-South trade. In: Jones, R., Krueger, A. O. (Eds.), The Political Economy of International Trade. Oxford: Basil Blackwell, pp. 90-107.

Diwan, I., Rodrik, D., 1991. Patents, appropriate technology, and North-South trade. Journal of International Economics 30 (1-2), 27-47.

Feenstra, R., Hanson, G., 2005. Ownership and control in outsourcing to China: Estimating the property-rights theory of the firm. Quarterly Journal of Economics 120 (2), 729-761.

Feenstra, R., Hong, C., Ma, H., Spencer, B., 2010. Contractual versus non-contractual trade: The role of institutions in China. Working paper, University of California, Davis.

Feenstra, R., Kee, H., 2008. Export variety and country productivity: Estimating the monopolistic competition model with endogenous productivity. Journal of International Economics 74 (2), $500-518$.

Gastanaga, V., Nugent, J., Pashamova, B., 1998. Host country reforms and FDI inflows: How much difference do they make? World Development 26 (7), 1299-1314.

Glass, A., Saggi, K., 1998. International technology transfer and the technology gap. Journal of Development Economics 55 (2), 369-398.

Goldberg, P., Khandelwal, A., Pavcnik, N., Topalova, P., 2010. Imported intermediate inputs and domestic product growth: Evidence from India. Quarterly Journal of Economics 125 (4), $1727-$ 1767. 
Gomes-Casseres, B., 1990. Firm ownership preferences and host government restrictions: An integrated approach. Journal of International Business Studies 21 (1), 1-22.

Grossman, G., Helpman, E., 1991a. Endogenous product cycles. Economic Journal 101 (408), 1214-1229.

Grossman, G., Helpman, E., 1991b. Quality ladders and product cycles. Quarterly Journal of Economics $106(2), 557-586$.

Grossman, G., Helpman, E., 2002. Integration versus outsourcing in industry equilibrium. Quarterly Journal of Economics 117 (1), 85-120.

Grossman, S. J., Hart, O. D., 1986. The costs and benefits of ownership: A theory of vertical and lateral integration. Journal of Political Economy 94 (4), 691-719.

Kobrin, S., 1987. Testing the bargaining hypothesis in the manufacturing sector in developing countries. International Organization 41 (4), 609-638.

Krugman, P., 1979a. Increasing returns, monopolistic competition, and international trade. Journal of International Economics 9 (4), 469 - 479.

Krugman, P., 1979b. A model of innovation, technology transfer, and the world distribution of income. Journal of Political Economy 87 (2), 253-266.

Lai, E., 1998. International intellectual property rights protection and the rate of product innovation. Journal of Development Economics 55 (1), 133-153.

Levchenko, A., 2007. Institutional quality and international trade. Review of Economic Studies $74(3), 791-819$.

Lu, Y., Png, I., Tao, Z., 2008. Do institutions not matter in China? Evidence from enterprise-level productivity growth. Working paper, University of Hong Kong. 
Mansfield, E., Romeo, A., 1980. Technology transfer to overseas subsidiaries by US-based firms. Quarterly Journal of Economics 95 (4), 737-750.

McLaren, J., 2000. "Globalization” and vertical structure. American Economic Review 90 (5), $1239-1254$.

NBS, National Bureau of Statistics of China, 1997-2007. China Population Statistics Yearbook. China Statistics Press, Beijing.

NBS, National Bureau of Statistics of China, 2005. Product Classification for Statistics (Temporary Version). China Statistics Press, Beijing.

NBS, National Bureau of Statistics of China, 2009a. China Compendium of Statistics 1949-2008. China Statistics Press, Beijing.

NBS, National Bureau of Statistics of China, 2009b. China Trade and External Economic Statistical Yearbook. China Statistics Press, Beijing.

NDRC, National Development and Reform Commission, 1995. The catalogue for the guidance of foreign investment industries. Revisions of 1997, 2002, 2004 and 2007.

NDRC, National Development and Reform Commission, 2007. China development zone review announcement catalogue.

Nunn, N., 2007. Relationship-specificity, incomplete contracts, and the pattern of trade. Quarterly Journal of Economics 122 (2), 569-600.

Romalis, J., 2004. Factor proportions and the structure of commodity trade. American Economic Review 94 (1), 67-97.

Sheng, L., Yang, D. T., 2011. Processing trade, ownership structure, and wage inequality: Theory and evidence from China. Working paper, University of California, Davis. 
Stock, J., Wright, J., Yogo, M., 2002. A survey of weak instruments and weak identification in generalized method of moments. Journal of Business and Economic Statistics 20 (4), 518-529.

TNICO, The Third National Industrial Census Office, 1997. The Data of the Third Industrial Census of the People's Republic of China in 1995, Industrial Volume. China Statistics Press, Beijing.

Vernon, R., 1966. International investment and international trade in the product cycle. Quarterly Journal of Economics 80 (2), 190-207.

Wang, J., 2010. The economic impact of special economic zones: Evidence from Chinese municipalities. Working paper, Hong Kong University of Science and Technology.

Wei, S., 2000. How taxing is corruption on international investors? Review of Economics and Statistics $82(1), 1-11$.

World Bank, 2008. Doing Business in China. Available at: www.doingbusiness.org/china.

Yang, G., Maskus, K., 2001. Intellectual property rights, licensing, and innovation in an endogenous product-cycle model. Journal of International Economics 53 (1), 169-187. 


\section{Appendix: Proof of Lemma 1}

We first derive the properties of $B^{O}(z)$ for $O \in\{A, V\}$. Consider the case in which the producer chooses an independent Southern firm to produce the intermediate input. With $\beta=1 / 2$, we have

$$
B^{A}(z)=\left[\phi+(1-\phi) \frac{1-1 / 2 \alpha}{1-\alpha}(1 / 2)^{\alpha /(1-\alpha)}\right]^{-\frac{1-\alpha}{\alpha z}}
$$

It is easy to show that $B^{A}(z)$ has the following proposition:

\section{Proposition 1}

(1) $B^{A}(1)>1, \lim _{z \rightarrow 0} B^{A}(z)=\infty, B_{z}^{A}(z)<0$, and $B_{\phi}^{A}(z)<0$.

(2) If $B^{A}(1)<\omega / \tau$, there exists a unique cutoff $\bar{z}_{N A}$, such that $B^{A}\left(\bar{z}_{N A}\right)=\omega / \tau$, and $B^{A}(z)>$ $\omega / \tau$ if $z<\bar{z}_{N A}$, and $B^{A}(z)<\omega / \tau$ if $z>\bar{z}_{N A}$.

Given $\alpha \in(0,1), f(x)=(1-\alpha x) x^{\frac{\alpha}{1-\alpha}}$ is an increasing function for $x \in[0,1]$, thus $\frac{1-1 / 2 \alpha}{1-\alpha}(1 / 2)^{\alpha /(1-\alpha)}<1$, and the term in the bracket of $B^{A}(z)$ is less than 1 . Therefore, it is easy to show $B^{A}(1)>1, \lim _{z \rightarrow 0} B^{A}(z)=\infty$, and $B_{z}^{A}(z)<0$ and $B_{\phi}^{A}(z)<0$. As shown in Figure $1, B^{A}(z)$ decreases in $z$. Thus, if $B^{A}(1)<\omega / \tau$, then there exists a unique cutoff $\bar{z}_{N A}$, such that $B^{A}\left(\bar{z}_{N A}\right)=\omega / \tau, B^{A}(z)>\omega / \tau$ if $z<\bar{z}_{N A}$, and $B^{A}(z)<\omega / \tau$ if $z>\bar{z}_{N A}$.

We can show that with the same assumptions in Antras(2005), the $B^{V}(z)$ curve has similar properties:

\section{Proposition 2}

(1) $B^{V}(1)>B^{A}(1), \lim _{z \rightarrow 0} B^{V}(z)=\infty$, and $B_{\phi}^{V}(z)<0$.

(2) If $\delta^{\alpha}<1 / 2$, i.e., $\beta^{V}<3 / 4$, then $B_{z}^{V}(z)<0$.

(3) If $B^{V}(1)<\omega / \tau$, there exists a unique cutoff $\bar{z}_{N V}$, such that $B^{V}\left(\bar{z}_{N V}\right)=\omega / \tau, B^{V}(z)>\omega / \tau$ if $z<\bar{z}_{N V}$, and $B^{V}(z)<\omega / \tau$ if $z>\bar{z}_{N V}$. 
(4) There exists a unique cutoff $\bar{z}_{A V}$, such that $B^{A}\left(\bar{z}_{A V}\right)=B^{V}\left(\bar{z}_{A V}\right), B^{A}(z)>B^{V}(z)$ if $z<$ $\bar{z}_{A V}$, and $B^{A}(z)<B^{V}(z)$ if $z>\bar{z}_{A V}$. Moreover, this cutoff $\bar{z}_{A V}$ is independent of $\phi$.

We know

$$
B^{V}(z)=\left[\phi+(1-\phi) \frac{1-\alpha \beta^{V}(1-z)-\alpha\left(1-\beta^{V}\right) z}{1-\alpha}\left[\left(\beta^{V}\right)^{1-z}\left(1-\beta^{V}\right)^{z}\right]^{\alpha /(1-\alpha)}\right]^{-\frac{1-\alpha}{\alpha z}}
$$

Hence, $B^{V}(1)=\left[\phi+(1-\phi) \frac{1-\alpha\left(1-\beta^{V}\right)}{1-\alpha}\left(1-\beta^{V}\right)^{\alpha /(1-\alpha)}\right]^{-\frac{1-\alpha}{\alpha}}$, and given the property of $f(x)$ and $\beta^{V} \in(1 / 2,1)$, we know $0<f\left(1-\beta^{V}\right)<f(1 / 2)$. Then, $\phi+(1-\phi) f\left(1-\beta^{V}\right)<$ $\phi+(1-\phi) f(1 / 2)$, and thus $B^{V}(1)>B^{A}(1)$.

Next, define $\Phi(z, \beta) \equiv \frac{1-\alpha[\beta(1-z)+(1-\beta) z]}{1-\alpha}\left[\beta^{1-z}(1-\beta)^{z}\right]^{\alpha /(1-\alpha)}$, which is less than $\frac{1-\alpha[\beta+(1-\beta)]}{1-\alpha}\left[1^{1-z} *\right.$ $\left.1^{z}\right]^{\alpha /(1-\alpha)}<1$. Therefore, $\phi+(1-\phi) \Phi(z, \beta)<1$, and a rising $\phi$ increases $(\phi+(1-\phi) \Phi(z, \beta))$ for a given $z$. Thus, $\lim _{z \rightarrow 0} B^{V}(z)=\infty$, and $B_{\phi}^{V}(z)<0$.

For proposition 2(2), if $\phi=0$, it reduces to the case in Antras (2005). Antras shows that $\delta^{\alpha}<1 / 2$ is the sufficient condition for $B_{z}^{V}(z)<0$. For the general case $\phi \in(0,1)$, this inequality becomes intractable. However, Matlab simulations for possible values of $\alpha, \phi, z$ suggest that this sufficient condition still holds. It is reasonable because as $\phi$ increases from 0 to 1 , the severity of contract incompleteness declines.

Given the propositions 2(1) and 2(2), and if $B^{V}(1)<\omega / \tau$, then there exists a unique cutoff $\bar{z}_{N V}$, such that $B^{V}\left(\bar{z}_{N V}\right)=\omega / \tau, B^{V}(z)>\omega / \tau$ if $z<\bar{z}_{N V}$, and $B^{V}(z)<\omega / \tau$ if $z>\bar{z}_{N V}$.

To derive proposition 2(4), we only need to compare $\Phi\left(z, \beta^{V}\right)$ and $\Phi\left(z, \beta^{A}\right)$. Let

$$
\Gamma(z)=\Phi\left(z, \beta^{V}\right) / \Phi\left(z, \beta^{A}\right)=\frac{1-\alpha\left[\left(\beta^{V}\right)(1-z)+\left(1-\beta^{V}\right) z\right]}{1-\alpha / 2}\left[2\left(\beta^{V}\right)^{1-z}\left(1-\beta^{V}\right)^{z}\right]^{\alpha /(1-\alpha)}
$$

First, to demonstrate $\Gamma(z)$ decreases in $z$, we only need to show

$$
\frac{\alpha}{1-\alpha} \ln \frac{\beta^{V}}{1-\beta^{V}}>\frac{\alpha\left(2 \beta^{V}-1\right)}{1-\alpha \beta^{V}-\alpha\left(1-2 \beta^{V}\right) z} .
$$


As the RHS decreases in $z$, it is no larger than $\frac{\alpha\left(2 \beta^{V}-1\right)}{1-\alpha \beta^{V}}$, which is less than the LHS. To show this, define $G(\beta)=\frac{\alpha}{1-\alpha} \ln \frac{\beta^{V}}{1-\beta^{V}}-\frac{\alpha\left(2 \beta^{V}-1\right)}{1-\alpha \beta^{V}}$. It is easy to show $G\left(\beta^{V}\right)$ is increasing in $\beta^{V}$; thus, $G\left(\beta^{V}\right)>G(1 / 2)=0$.

Moreover, $\Gamma(0)=\frac{1-\alpha \beta^{V}}{1-\alpha / 2}\left[2 \beta^{V}\right]^{\alpha /(1-\alpha)}$ and $\Gamma(1)=\frac{1-\alpha\left(1-\beta^{V}\right)}{1-\alpha / 2}\left[2\left(1-\beta^{V}\right)\right]^{\alpha /(1-\alpha)}$. Given $\alpha \in$ $(0,1), g(x)=\frac{1-\alpha x}{1-\alpha / 2}[2 x]^{\alpha /(1-\alpha)}$ increases in $x$ for $x \in(0,1)$. Hence, $\beta^{V}>1 / 2$ implies that $g\left(1-\beta^{V}\right)<g(1 / 2)=1<g\left(\beta^{V}\right)$, which give the result $\Gamma(1)<1<\Gamma(0)$. Therefore, there exists a unique cutoff $\bar{z}_{A V}$, such that $B^{A}\left(\bar{z}_{A V}\right)=B^{V}\left(\bar{z}_{A V}\right), B^{A}(z)>B^{V}(z)$ if $z<\bar{z}_{A V}$, and $B^{A}(z)<B^{V}(z)$ if $z>\bar{z}_{A V}$. Moreover, because $\Phi\left(z, \beta^{V}\right)$ and $\Phi\left(z, \beta^{A}\right)$ are independent of $\phi$, the cutoff $\bar{z}_{A V}$ is also independent of $\phi$.

Proposition 3 If $\bar{z}_{N V}<\bar{z}_{N A}<\bar{z}_{A V}$, then the Lemma 1 holds.

Based on propositions 1(2) and 2(3), we know the intermediate input is produced in the North if $z<\min \left\{\bar{z}_{N A}, \bar{z}_{N V}\right\}$. Moreover, it is easy to verify that three cutoffs must satisfy one of the following order: (1) $\bar{z}_{A V}=\bar{z}_{N A}=\bar{z}_{N V}$, (2) $\bar{z}_{A V}<\bar{z}_{N A}<\bar{z}_{N V}$, and (3) $\bar{z}_{N V}<\bar{z}_{N A}<\bar{z}_{A V}$. The first case has small likelihood to happen, and in the second case, the vertical integration will be dominated by the choice of Northern production and arm's length production in the South. This case is not interesting. For the third case, for $z<\bar{z}_{N V}$, its intermediate input is produced in the North. For $\bar{z}_{N V}<z<\bar{z}_{A V}$, its intermediate input is produced by an integrated firm in the South. And, for $z>\bar{z}_{A V}$, its intermediate input is produced by an independent firm in the South. Thus, the lemma 1 holds. 


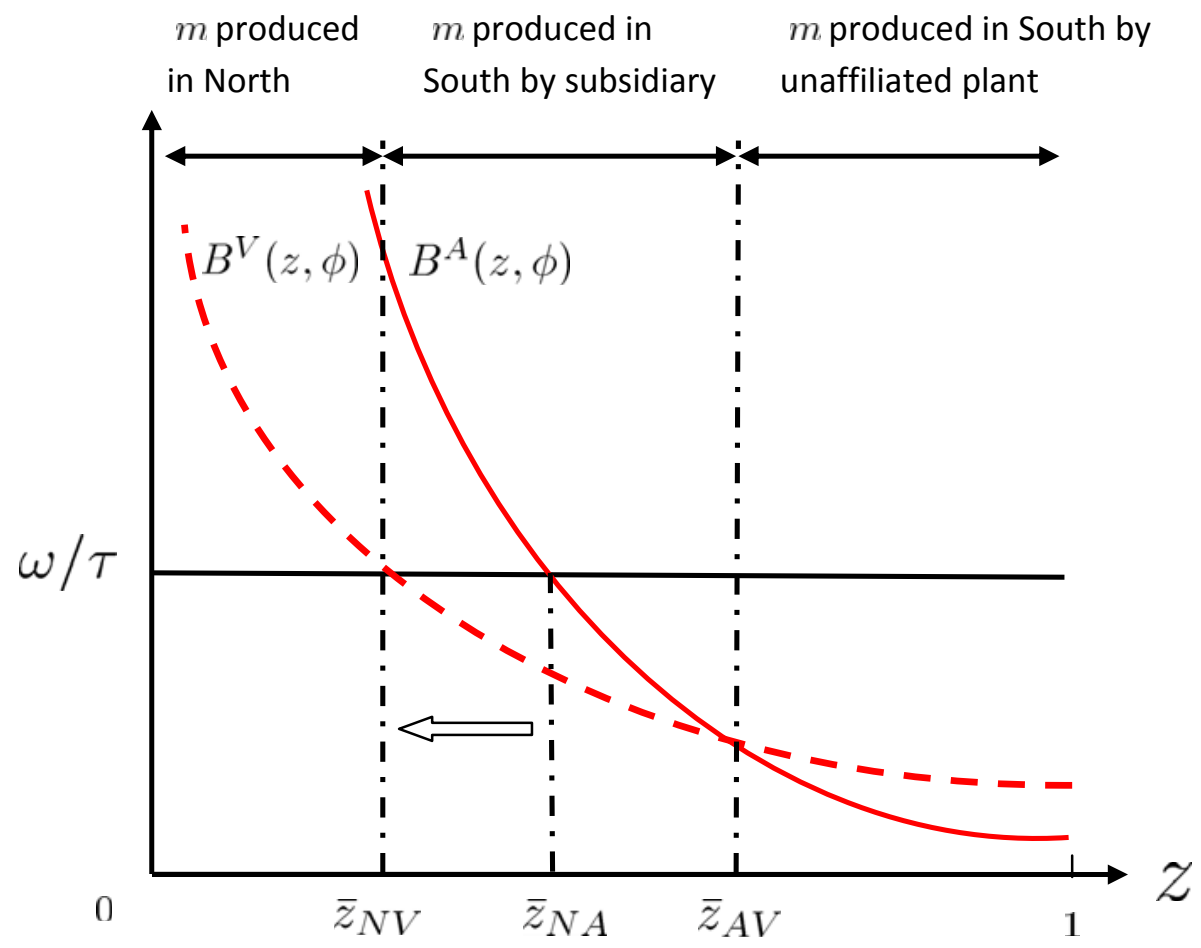

Figure 1: Effect of Ownership Liberalization on the Extensive Margin 


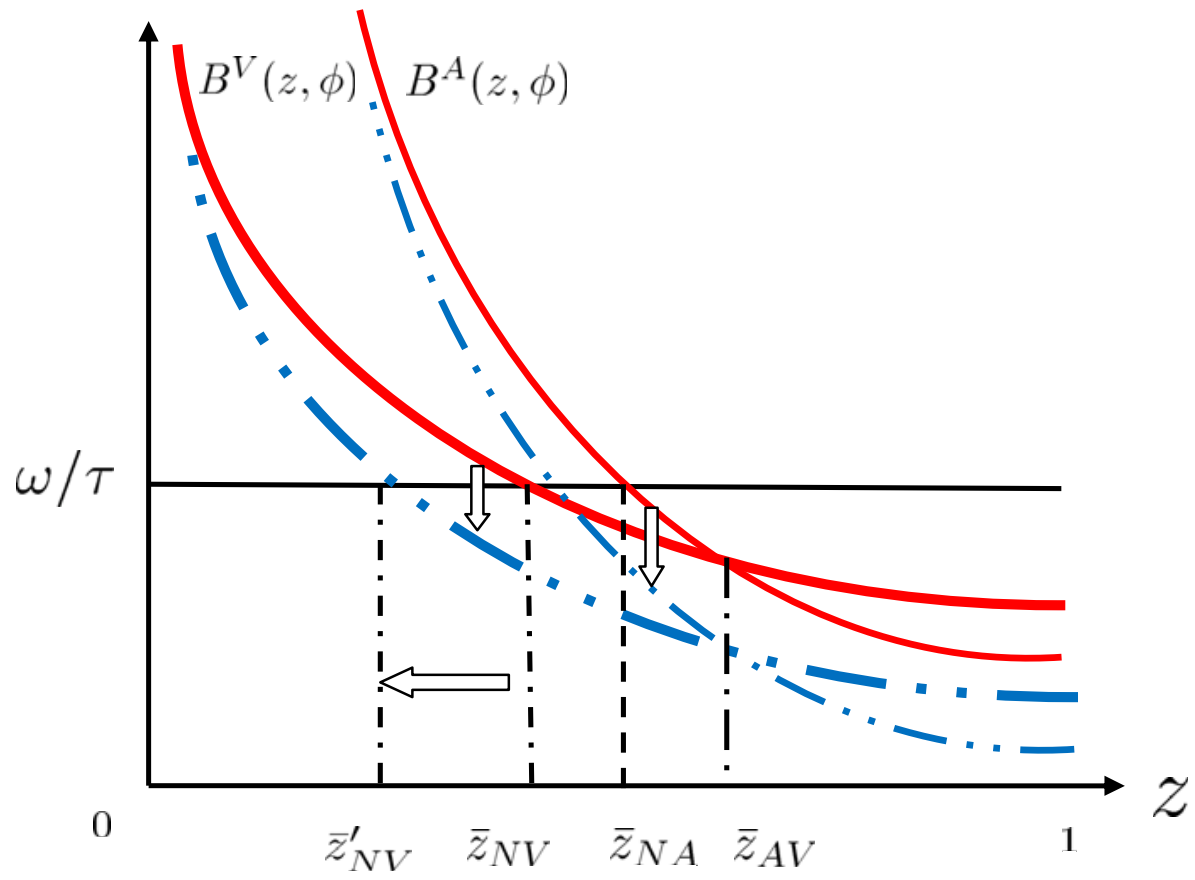

Figure 2: Effect of Contract Enforcement on the Extensive Margin

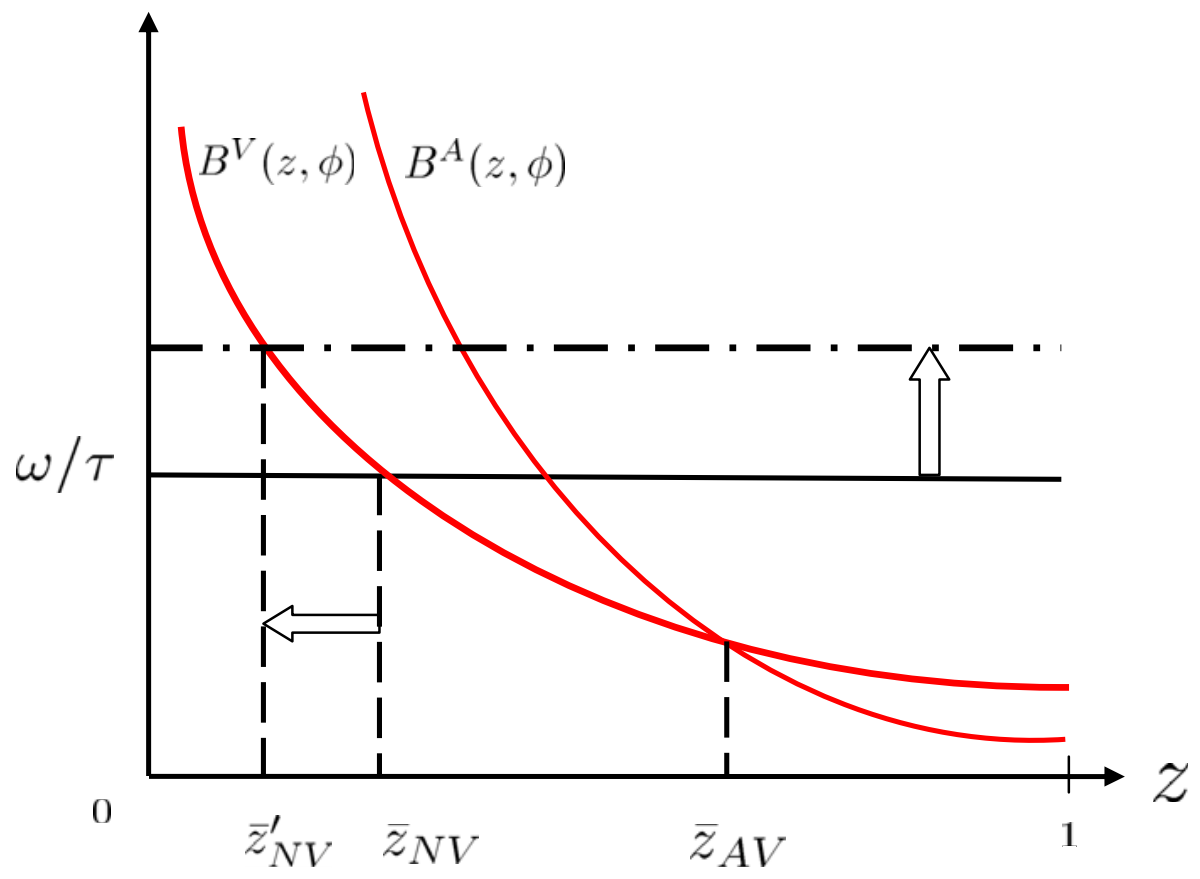

Figure 3: Effect of Trade Cost Reduction on the Extensive Margin 


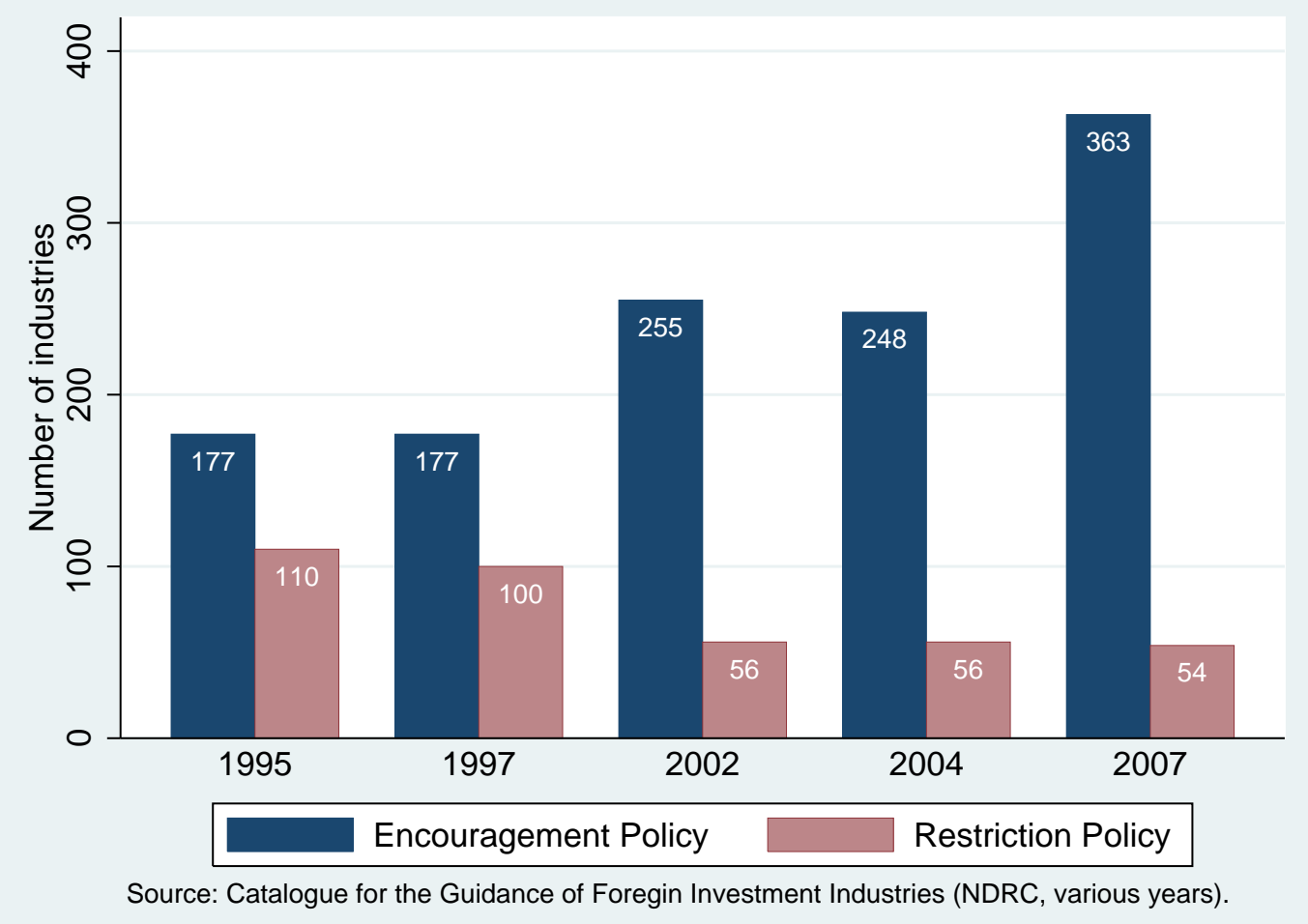

Figure 4: Measure of Ownership Liberalization 1995-2007 
Table 1: Summary Statistics of China's Processing Export

\begin{tabular}{|c|c|c|c|c|c|c|c|c|}
\hline \multirow[t]{2}{*}{ Year } & \multirow{2}{*}{$\begin{array}{l}\text { Processing export } \\
\text { (billion dollar) }\end{array}$} & \multirow{2}{*}{$\begin{array}{c}\text { Share of } \\
\text { intrafirm export }\end{array}$} & \multicolumn{3}{|c|}{ Number of varieties (thousand) $^{\mathrm{a}}$} & \multicolumn{3}{|c|}{ Extensive Margin Index ${ }^{b}$} \\
\hline & & & Total & Intrafirm & Arm's-length & Total & Intrafirm & Arm's-length \\
\hline 1997 & 99 & 0.29 & 56.4 & 25.9 & 48.4 & 0.42 & 0.27 & 0.33 \\
\hline 1998 & 104 & 0.32 & 58.7 & 28.7 & 49.2 & 0.43 & 0.27 & 0.34 \\
\hline 1999 & 111 & 0.36 & 61.0 & 31.5 & 50.3 & 0.43 & 0.30 & 0.35 \\
\hline 2000 & 137 & 0.38 & 63.5 & 34.6 & 51.7 & 0.44 & 0.31 & 0.35 \\
\hline 2001 & 147 & 0.41 & 55.6 & 30.8 & 42.7 & 0.45 & 0.33 & 0.35 \\
\hline 2002 & 179 & 0.46 & 71.1 & 42.9 & 55.1 & 0.48 & 0.38 & 0.42 \\
\hline 2003 & 241 & 0.52 & 67.3 & 41.9 & 48.9 & 0.56 & 0.45 & 0.44 \\
\hline 2004 & 327 & 0.56 & 76.3 & 48.4 & 54.7 & 0.56 & 0.47 & 0.46 \\
\hline 2005 & 415 & 0.60 & 84.9 & 55.3 & 59.9 & 0.58 & 0.49 & 0.50 \\
\hline 2006 & 509 & 0.63 & 92.5 & 61.6 & 63.8 & 0.59 & 0.51 & 0.52 \\
\hline 2007 & 616 & 0.64 & 98.8 & 66.6 & 67.8 & 0.77 & 0.65 & 0.67 \\
\hline
\end{tabular}

${ }^{\mathrm{a}}$ Variety is defined as an eight-digit HS product-destination country pair. Note that the total number of varieties is not equal to the sum of the varieties by intrafirm and arm's length export because different firms can export the same variety.

b This index of extensive margin is based on Feenstra and Kee (2008), as explained in Equation (4). 
Table 2: Determinants of the Extensive Margin in Processing Export

\begin{tabular}{|c|c|c|c|c|c|c|}
\hline \multirow[b]{2}{*}{ Independent variable } & \multicolumn{6}{|c|}{ Dependent variable: $\log ($ Extensive Margin Index $)$} \\
\hline & $\begin{array}{l}\text { OLS } \\
(1)\end{array}$ & $\begin{array}{l}\text { IV } \\
(2)\end{array}$ & $\begin{array}{l}\text { OLS } \\
\text { (3) }\end{array}$ & $\begin{array}{l}\text { IV } \\
(4)\end{array}$ & $\begin{array}{l}\text { OLS } \\
(5)\end{array}$ & $\begin{array}{l}\text { IV } \\
(6)\end{array}$ \\
\hline Intrafirm indicator & $\begin{array}{c}-0.461^{* * *} \\
(0.035)\end{array}$ & $\begin{array}{c}-0.482^{* * *} \\
(0.034)\end{array}$ & $\begin{array}{c}-1.151^{* * * *} \\
(0.107)\end{array}$ & $\begin{array}{c}-1.304 * * * \\
(0.170)\end{array}$ & $\begin{array}{c}-0.708^{* * *} \\
(0.132)\end{array}$ & $\begin{array}{c}-0.570^{* * *} \\
(0.199)\end{array}$ \\
\hline Encouragement policy & $\begin{array}{c}0.305 * * * \\
(0.059)\end{array}$ & $\begin{array}{c}0.303 * * * \\
(0.059)\end{array}$ & $\begin{array}{c}0.235 * * * \\
(0.063)\end{array}$ & $\begin{array}{c}0.220 * * * \\
(0.062)\end{array}$ & $\begin{array}{c}0.226 * * * \\
(0.063)\end{array}$ & $\begin{array}{c}0.209 * * * \\
(0.061)\end{array}$ \\
\hline Restriction policy & $\begin{array}{c}-0.166 * * * \\
(0.050)\end{array}$ & $\begin{array}{c}-0.159 * * * \\
(0.050)\end{array}$ & $\begin{array}{l}-0.057 \\
(0.055)\end{array}$ & $\begin{array}{l}-0.031 \\
(0.055)\end{array}$ & $\begin{array}{l}-0.055 \\
(0.053)\end{array}$ & $\begin{array}{l}-0.040 \\
(0.054)\end{array}$ \\
\hline Court efficiency & $\begin{array}{c}0.219 \\
(0.289)\end{array}$ & $\begin{array}{c}0.429 \\
(0.566)\end{array}$ & $\begin{array}{l}-0.115 \\
(0.322)\end{array}$ & $\begin{array}{l}-0.331 \\
(0.675)\end{array}$ & $\begin{array}{l}-0.079 \\
(0.321)\end{array}$ & $\begin{array}{c}0.095 \\
(0.614)\end{array}$ \\
\hline Policy zones & $\begin{array}{c}0.097 * * * \\
(0.011)\end{array}$ & $\begin{array}{c}0.109 * * * \\
(0.011)\end{array}$ & $\begin{array}{c}0.076 \text { *** } \\
(0.011)\end{array}$ & $\begin{array}{c}0.087 * * * \\
(0.011)\end{array}$ & $\begin{array}{c}0.076^{* * * *} \\
(0.011)\end{array}$ & $\begin{array}{c}0.091^{* * * *} \\
(0.011)\end{array}$ \\
\hline Intrafirm $\times$ encouragement & & & $\begin{array}{c}0.169 * * * \\
(0.042)\end{array}$ & $\begin{array}{c}0.168 * * * \\
(0.041)\end{array}$ & $\begin{array}{c}-0.520 * * * \\
(0.160)\end{array}$ & $\begin{array}{c}-0.776 * * * \\
(0.188)\end{array}$ \\
\hline Intrafirm $\times$ restriction & & & $\begin{array}{c}-0.278 * * * \\
(0.047)\end{array}$ & $\begin{array}{c}-0.267 * * * \\
(0.046)\end{array}$ & $\begin{array}{c}-0.387 * * \\
(0.165)\end{array}$ & $\begin{array}{c}-0.753 * * * \\
(0.252)\end{array}$ \\
\hline Intrafirm $\times$ court efficiency & & & $\begin{array}{c}0.911^{* *} \\
(0.409)\end{array}$ & $\begin{array}{c}1.633 * * \\
(0.667)\end{array}$ & $\begin{array}{l}-0.291 \\
(0.428)\end{array}$ & $\begin{array}{l}-0.756 \\
(0.713)\end{array}$ \\
\hline Intrafirm $\times$ zones & & & $\begin{array}{c}0.040 * * * \\
(0.006)\end{array}$ & $\begin{array}{c}0.030 * * * \\
(0.006)\end{array}$ & $\begin{array}{c}0.035 * * * \\
(0.006)\end{array}$ & $\begin{array}{c}0.033^{* * *} * \\
(0.006)\end{array}$ \\
\hline Intrafirm $\times$ encouragement $\times$ court efficiency & & & & & $\begin{array}{c}2.247 * * * \\
(0.488)\end{array}$ & $\begin{array}{c}3.201 * * * \\
(0.614)\end{array}$ \\
\hline Intrafirm $\times$ restriction $\times$ court efficiency & & & & & $\begin{array}{l}-0.571 \\
(0.533)\end{array}$ & $\begin{array}{c}0.991 \\
(0.846)\end{array}$ \\
\hline Intrafirm $\times$ encouragement $\times$ zones & & & & & $\begin{array}{l}-0.004 \\
(0.006)\end{array}$ & $\begin{array}{l}-0.009 \\
(0.006)\end{array}$ \\
\hline Intrafirm $\times$ restriction $\times$ zones & & & & & $\begin{array}{c}0.030 * * * \\
(0.007) \\
\end{array}$ & $\begin{array}{c}0.018 * * \\
(0.007) \\
\end{array}$ \\
\hline Ln(distance) & $\begin{array}{c}-0.183^{* * *} \\
(0.038)\end{array}$ & $\begin{array}{c}-0.151^{* * *} \\
(0.045)\end{array}$ & $\begin{array}{c}-0.177 \text { *** } \\
(0.039)\end{array}$ & $\begin{array}{c}-0.150 * * * \\
(0.046)\end{array}$ & $\begin{array}{c}-0.176^{* * * *} \\
(0.039)\end{array}$ & $\begin{array}{c}-0.135 * * * \\
(0.044)\end{array}$ \\
\hline Coastal & $\begin{array}{c}0.852 * * * \\
(0.090)\end{array}$ & $\begin{array}{c}0.815^{* * *} \\
(0.115)\end{array}$ & $\begin{array}{c}0.893 * * * \\
(0.091)\end{array}$ & $\begin{array}{c}0.867 * * * \\
(0.117)\end{array}$ & $\begin{array}{c}0.882 * * * \\
(0.091)\end{array}$ & $\begin{array}{c}0.789 * * * \\
(0.110)\end{array}$ \\
\hline Border & $\begin{array}{c}0.073 \\
(0.071)\end{array}$ & $\begin{array}{c}0.042 \\
(0.071)\end{array}$ & $\begin{array}{c}0.089 \\
(0.072)\end{array}$ & $\begin{array}{c}0.033 \\
(0.071)\end{array}$ & $\begin{array}{c}0.088 \\
(0.071)\end{array}$ & $\begin{array}{c}0.024 \\
(0.070)\end{array}$ \\
\hline $\operatorname{Ln}$ (population density) & $\begin{array}{c}0.352 * * * \\
(0.040)\end{array}$ & $\begin{array}{c}0.362 * * * \\
(0.040)\end{array}$ & $\begin{array}{c}0.355 * * * \\
(0.041)\end{array}$ & $\begin{array}{c}0.322 * * * \\
(0.039)\end{array}$ & $\begin{array}{c}0.359 * * * \\
(0.041)\end{array}$ & $\begin{array}{c}0.343 * * * \\
(0.038)\end{array}$ \\
\hline $\operatorname{Ln}($ real output $)$ & $\begin{array}{c}0.192 * * * \\
(0.061)\end{array}$ & $\begin{array}{c}0.146^{* *} \\
(0.060)\end{array}$ & $\begin{array}{c}0.214 * * * \\
(0.062)\end{array}$ & $\begin{array}{c}0.228 * * * \\
(0.059)\end{array}$ & $\begin{array}{c}0.212 * * * \\
(0.062)\end{array}$ & $\begin{array}{c}0.204 * * * \\
(0.057)\end{array}$ \\
\hline Skill intensity $\times$ college share & $\begin{array}{c}0.006 * * * \\
(0.001)\end{array}$ & $\begin{array}{c}0.006 * * * \\
(0.001)\end{array}$ & $\begin{array}{c}0.006 * * * \\
(0.001)\end{array}$ & $\begin{array}{c}0.006 * * * \\
(0.001)\end{array}$ & $\begin{array}{c}0.006 * * * \\
(0.001)\end{array}$ & $\begin{array}{c}0.005^{* * * *} \\
(0.001)\end{array}$ \\
\hline Capital intensity $\times$ capital output ratio & $\begin{array}{c}0.040 * * * \\
(0.011)\end{array}$ & $\begin{array}{c}0.034 * * * \\
(0.012)\end{array}$ & $\begin{array}{c}0.041 * * * \\
(0.011)\end{array}$ & $\begin{array}{c}0.034 * * * \\
(0.013)\end{array}$ & $\begin{array}{c}0.040 * * * \\
(0.011)\end{array}$ & $\begin{array}{c}0.031 * * \\
(0.012)\end{array}$ \\
\hline Constant & $\begin{array}{c}-4.428 * * * \\
(0.602) \\
\end{array}$ & $\begin{array}{c}-4.300 * * * \\
(0.683) \\
\end{array}$ & $\begin{array}{c}-4.377 * * * * \\
(0.620) \\
\end{array}$ & $\begin{array}{c}-4.597 * * * \\
(0.702) \\
\end{array}$ & $\begin{array}{c}-4.346^{* * * *} \\
(0.622) \\
\end{array}$ & $\begin{array}{c}-4.484 * * * * \\
(0.682) \\
\end{array}$ \\
\hline First-stage F-test & & 91.96 & & $>43.36$ & & $>21.27$ \\
\hline Year dummy & yes & yes & yes & yes & yes & yes \\
\hline $\begin{array}{l}\text { Industrial dummy } \\
N\end{array}$ & $\begin{array}{c}\text { yes } \\
28555\end{array}$ & $\begin{array}{c}\text { yes } \\
28555\end{array}$ & $\begin{array}{c}\text { yes } \\
28555\end{array}$ & $\begin{array}{c}\text { yes } \\
28555\end{array}$ & $\begin{array}{c}\text { yes } \\
28555\end{array}$ & $\begin{array}{c}\text { yes } \\
28555\end{array}$ \\
\hline$R^{2}$ & 0.466 & 0.466 & 0.471 & 0.469 & 0.472 & 0.470 \\
\hline
\end{tabular}

Note: Variety is defined as an eight-digit HS product-destination country pair. The panel covers 29 provinces and 112 industries in 1997-2007. Cluster robust standard errors are in parentheses. *, **, and *** indicate significance at the 10,5, and 1 percent levels. 
Table 3: Determinants of Processing Export: Alternative Measures of Extensive Margin

\begin{tabular}{|c|c|c|c|c|c|c|}
\hline Independent variable & \multicolumn{3}{|c|}{$\log (\text { Number of Variety })^{\mathrm{a}}$} & \multicolumn{3}{|c|}{$\log (\text { Extensive Margin Index })^{b}$} \\
\hline Intrafirm indicator & $\begin{array}{c}-0.390 * * * \\
(0.034)\end{array}$ & $\begin{array}{c}-1.382 * * * \\
(0.146)\end{array}$ & $\begin{array}{c}-0.976^{* * *} * \\
(0.177)\end{array}$ & $\begin{array}{c}-0.392 * * * \\
(0.024)\end{array}$ & $\begin{array}{c}-1.014 * * * \\
(0.127)\end{array}$ & $\begin{array}{c}-0.488 * * * \\
(0.147)\end{array}$ \\
\hline Encouragement policy & $\begin{array}{c}0.092 * * * \\
(0.035)\end{array}$ & $\begin{array}{c}0.008 \\
(0.038)\end{array}$ & $\begin{array}{c}0.014 \\
(0.038)\end{array}$ & $\begin{array}{c}0.233 * * * \\
(0.044)\end{array}$ & $\begin{array}{c}0.189 * * * \\
(0.046)\end{array}$ & $\begin{array}{c}0.174 * * * \\
(0.045)\end{array}$ \\
\hline Restriction policy & $\begin{array}{c}-0.023 \\
(0.038)\end{array}$ & $\begin{array}{c}0.101 * * \\
(0.042)\end{array}$ & $\begin{array}{c}0.086 * * \\
(0.041)\end{array}$ & $\begin{array}{c}-0.139 * * * \\
(0.036)\end{array}$ & $\begin{array}{l}-0.039 \\
(0.040)\end{array}$ & $\begin{array}{c}-0.041 \\
(0.039)\end{array}$ \\
\hline Court efficiency & $\begin{array}{c}0.519 \\
(0.656)\end{array}$ & $\begin{array}{c}-0.381 \\
(0.702)\end{array}$ & $\begin{array}{l}-0.126 \\
(0.631)\end{array}$ & $\begin{array}{c}0.610 \\
(0.484)\end{array}$ & $\begin{array}{c}0.002 \\
(0.552)\end{array}$ & $\begin{array}{c}0.316 \\
(0.538)\end{array}$ \\
\hline Policy zones & $\begin{array}{c}0.120 * * * \\
(0.012)\end{array}$ & $\begin{array}{c}0.098 * * * \\
(0.012)\end{array}$ & $\begin{array}{c}0.104 * * * \\
(0.012)\end{array}$ & $\begin{array}{c}0.083 * * * \\
(0.009)\end{array}$ & $\begin{array}{c}0.069 * * * \\
(0.008)\end{array}$ & $\begin{array}{c}0.072 * * * \\
(0.008)\end{array}$ \\
\hline Intrafirm $\times$ encouragement & & $\begin{array}{c}0.221 * * * \\
(0.031)\end{array}$ & $\begin{array}{c}-0.387 * * * \\
(0.135)\end{array}$ & & $\begin{array}{c}0.111 * * * \\
(0.027)\end{array}$ & $\begin{array}{c}-0.592 * * * \\
(0.125)\end{array}$ \\
\hline Intrafirm $\times$ zones & & $\begin{array}{c}0.030 * * * \\
(0.006)\end{array}$ & $\begin{array}{c}0.038 * * * \\
(0.005)\end{array}$ & & $\begin{array}{c}0.022 * * * \\
(0.004)\end{array}$ & $\begin{array}{c}0.015^{* * *} * \\
(0.004)\end{array}$ \\
\hline Intrafirm $\times$ encouragement $\times$ court efficiency & & & $\begin{array}{c}2.123 * * * \\
(0.450)\end{array}$ & & & $\begin{array}{c}2.034 * * * \\
(0.420)\end{array}$ \\
\hline Intrafirm $\times$ restriction $\times$ court efficiency & & & $\begin{array}{c}0.510 \\
(0.655)\end{array}$ & & & $\begin{array}{c}0.467 \\
(0.642)\end{array}$ \\
\hline Intrafirm $\times$ encouragement $\times$ zones & & & $\begin{array}{c}-0.009 * * \\
(0.004)\end{array}$ & & & $\begin{array}{c}0.005 \\
(0.004)\end{array}$ \\
\hline Intrafirm $\times$ restriction $\times$ zones & & & $\begin{array}{c}-0.003 \\
(0.006)\end{array}$ & & & $\begin{array}{c}0.021 * * * \\
(0.006)\end{array}$ \\
\hline
\end{tabular}

\footnotetext{
Variety is defined as an eight-digit HS product-destination country pair.

b Variety is defined as an eight-digit HS product using Feenstra and Kee's (2008) index.

Note: The panel covers 29 provinces and 112 industries in 1997-2007. All regressions are estimated by GMM, with instruments for court efficiency and its interactions. For brevity, we do not report the coefficients for the constant and the control variables specified in Table 2. Cluster robust standard errors are in parentheses. *,**, and *** indicate significance at the 10 , 5 , and 1 percent levels.
} 
Table 4: Determinants of the Value of Processing Export

\begin{tabular}{|c|c|c|c|}
\hline \multirow[b]{2}{*}{ Independent variable } & \multicolumn{3}{|c|}{ Dependent variable: $\log$ (Export Value) } \\
\hline & (1) & (2) & (3) \\
\hline Intrafirm indicator & $\begin{array}{c}-0.667 * * * \\
(0.051)\end{array}$ & $\begin{array}{c}-1.821 * * * \\
(0.219)\end{array}$ & $\begin{array}{c}-1.111 * * * \\
(0.304)\end{array}$ \\
\hline Encouragement policy & $\begin{array}{c}0.300 * * * \\
(0.076)\end{array}$ & $\begin{array}{c}0.228 * * * \\
(0.083)\end{array}$ & $\begin{array}{c}0.193 * * \\
(0.082)\end{array}$ \\
\hline Restriction policy & $\begin{array}{c}-0.153^{* *} \\
(0.063)\end{array}$ & $\begin{array}{l}-0.035 \\
(0.069)\end{array}$ & $\begin{array}{l}-0.047 \\
(0.068)\end{array}$ \\
\hline Court efficiency & $\begin{array}{c}0.121 \\
(0.962)\end{array}$ & $\begin{array}{l}-0.712 \\
(1.060)\end{array}$ & $\begin{array}{c}0.420 \\
(0.921)\end{array}$ \\
\hline Policy zones & $\begin{array}{c}0.135 * * * \\
(0.017)\end{array}$ & $\begin{array}{c}0.110 * * * \\
(0.017)\end{array}$ & $\begin{array}{c}0.121 * * * \\
(0.016)\end{array}$ \\
\hline Intrafirm $\times$ encouragement & & $\begin{array}{c}0.131 * * \\
(0.059)\end{array}$ & $\begin{array}{c}-1.095 * * * \\
(0.251)\end{array}$ \\
\hline Intrafirm $\times$ restriction & & $\begin{array}{c}-0.275^{* * *} * \\
(0.061)\end{array}$ & $\begin{array}{c}0.071 \\
(0.363)\end{array}$ \\
\hline Intrafirm $\times$ court efficiency & & $\begin{array}{c}1.764 * * \\
(0.872)\end{array}$ & $\begin{array}{c}-0.677 \\
(1.085)\end{array}$ \\
\hline Intrafirm $\times$ zones & & $\begin{array}{c}0.061 * * * \\
(0.009)\end{array}$ & $\begin{array}{c}0.068 * * * \\
(0.009)\end{array}$ \\
\hline Intrafirm $\times$ encouragement $\times$ court efficiency & & & $\begin{array}{c}4.253 * * * \\
(0.838)\end{array}$ \\
\hline Intrafirm $\times$ restriction $\times$ court efficiency & & & $\begin{array}{l}-1.188 \\
(1.284)\end{array}$ \\
\hline Intrafirm $\times$ encouragement $\times$ zones & & & $\begin{array}{l}-0.015^{*} \\
(0.008)\end{array}$ \\
\hline Intrafirm $\times$ restriction $\times$ zones & & & $\begin{array}{c}0.005 \\
(0.011) \\
\end{array}$ \\
\hline First-stage F-test & 91.96 & $>43.36$ & $>21.27$ \\
\hline The constant and control variables & yes & yes & yes \\
\hline Year dummy & yes & yes & yes \\
\hline Industrial dummy & yes & yes & yes \\
\hline$N$ & 28555 & 28555 & 28555 \\
\hline$R^{2}$ & 0.477 & 0.482 & 0.482 \\
\hline
\end{tabular}

Note: The dependent variable is the log export value to all countries. The panel covers 29 provinces and 112 industries in 1997-2007. All regressions are estimated by GMM, with instruments for court efficiency and its interactions. For brevity, we do not report the coefficients for the constant and the control variables specified in Table 2. Cluster robust standard errors are in parentheses. ${ }^{*}, * *$, and $* * *$ indicate significance at the 10 , 5 , and 1 percent levels. 
Table 5: Determinants of Processing Export to High-income Countries

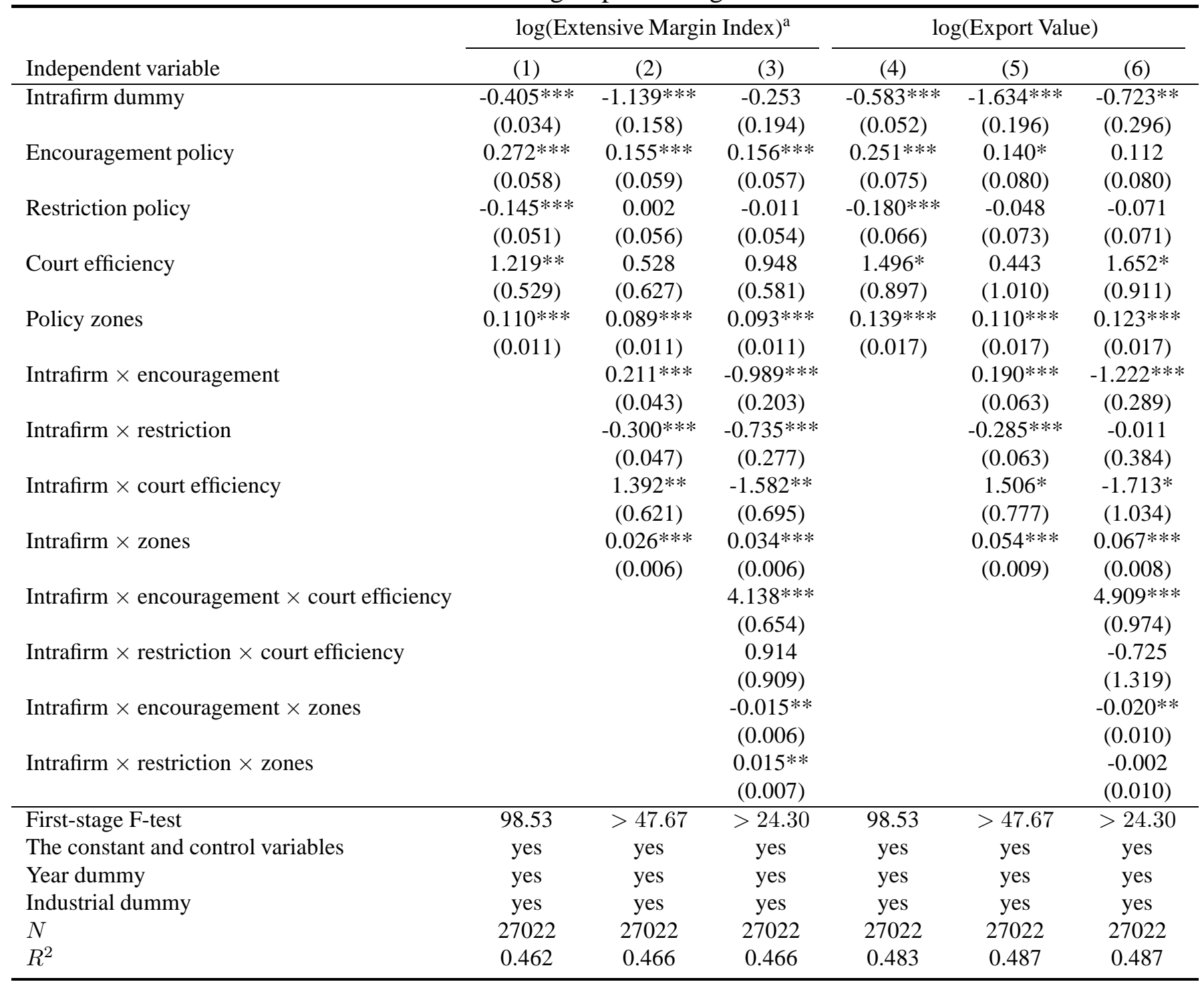

a Variety is defined as an eight-digit HS product-country pair using Feenstra and Kee's (2008) index.

Note: The sample covers China's processing export to high-income countries. The panel covers 29 provinces and 112 industries in 1997-2007. All regressions are estimated by GMM, with instruments for court efficiency and its interactions. For brevity, we do not report the coefficients for the constant and the control variables specified in Table 2. Cluster robust standard errors are in parentheses. *,**, and *** indicate significance at the 10,5 , and 1 percent levels. 